NBER WORKING PAPER SERIES

\title{
DID VIETNAM VETERANS GET SICKER IN THE 1990S? THE COMPLICATED EFFECTS OF MILITARY SERVICE ON SELF-REPORTED HEALTH
}

\author{
Joshua D. Angrist \\ Stacey H. Chen \\ Brigham R. Frandsen \\ Working Paper 14781 \\ http://www.nber.org/papers/w14781
}

\author{
NATIONAL BUREAU OF ECONOMIC RESEARCH \\ 1050 Massachusetts Avenue \\ Cambridge, MA 02138 \\ March 2009
}

This study was conducted while the authors were Special Sworn Status researchers of the U.S. Census Bureau at the Boston Research Data Center. Research results and conclusions expressed are those of the authors and do not necessarily reflect the views of the Census Bureau. This paper has been screened to ensure that no confidential data are revealed. Special thanks go to B.K. Atrostic, Jim Davis, and Brian Holly for help with the data used in this study, and to David Autor for helpful discussions and comments. We gratefully acknowledge funding from the National Science Foundation. The views expressed herein are those of the author(s) and do not necessarily reflect the views of the National Bureau of Economic Research.

NBER working papers are circulated for discussion and comment purposes. They have not been peerreviewed or been subject to the review by the NBER Board of Directors that accompanies official NBER publications.

(C) 2009 by Joshua D. Angrist, Stacey H. Chen, and Brigham R. Frandsen. All rights reserved. Short sections of text, not to exceed two paragraphs, may be quoted without explicit permission provided that full credit, including $(\mathcal{C}$ notice, is given to the source. 
Did Vietnam Veterans Get Sicker in the 1990s? The Complicated Effects of Military Service on Self-Reported Health

Joshua D. Angrist, Stacey H. Chen, and Brigham R. Frandsen

NBER Working Paper No. 14781

March 2009

JEL No. H55,H59,I12,I38,J22

\section{ABSTRACT}

The veterans disability compensation (VDC) program, which provides a monthly stipend to disabled veterans, is the third largest American disability insurance program. Since the late 1990s, VDC growth has been driven primarily by an increase in claims from Vietnam veterans, raising concerns about costs as well as health. We use the draft lottery to study the long-term effects of Vietnam-era military service on health and work in the 2000 Census. These estimates show no significant overall effects on employment or work-related disability status, with a small effect on non-work-related disability for whites. On the other hand, estimates for white men with low earnings potential show a large negative impact on employment and a marked increase in non-work-related disability rates. The differential impact of Vietnam-era service on low-skill men cannot be explained by more combat or war-theatre exposure for the least educated, leaving the relative attractiveness of VDC for less skilled men and the work disincentives embedded in the VDC system as a likely explanation.

Joshua D. Angrist

Department of Economics

MIT, E52-353

50 Memorial Drive

Cambridge, MA 02142-1347

and NBER

angrist@mit.edu

Stacey H. Chen

Horton Hall

Department of Economics

Royal Holloway Universtiy of London

Egham Hill

Tw20 0Ex

United Kingdon

Stacey.H.Chen@rhul.ac.uk
Brigham R. Frandsen

Department of Economics

MIT, E52-354

50 Memorial Drive

Cambridge, MA 02142-1347

frandsen@nber.org 


\section{Introduction}

The difficulties faced by many Afghanistan and Iraq war veterans have once again drawn attention to the fact that military service can have long-term health consequences. Care for injured and disabled veterans imposes a burden on soldiers, their families, and, in a less personal but still important way, on the government agencies that provide health care and disability insurance to veterans. These social insurance systems support almost three million sick and disabled veterans. Veterans Administration (VA) support programs increasingly serve a relatively young population made up of veterans of post-Korea conflicts. Vietnam veterans constitute the largest group of veterans receiving veterans disability compensation (VDC), with almost one million beneficiaries, about one third of the total. At the end of fiscal year 2006, the population receiving VDC amounted to roughly 12 percent of Vietnam-era veterans and 15 percent of Gulf War veterans, exceeding VDC take-up rates of 5 percent among Korean-era veterans and 10 percent among veterans of WWII. Moreover, payments to Vietnam veterans have increased to almost half of VDC costs, partly because Vietnam veterans are disproportionately likely to receive the maximum payment allowed (Veterans Benefits Administration, 2007).

The most visible health concerns for veterans are the long-term consequences of combat injury. Battlefield injuries can be individually devastating and socially costly for years after a conflict ends. Fortunately, acute injuries are less common among veterans of recent conflicts than they were in WWII (U.S. Bureau of the Census, 2006). At the same time, an increasing fraction of veteran disability claims in the past two decades has been for chronic conditions that were not necessarily apparent on the battlefield. These conditions include post-traumatic stress disorder (PTSD), hearing loss, and diabetes. Evidence for the importance of PTSD among Vietnam veterans comes in part from the pioneering draft-lottery study by Hearst, Newman, and Hulley (1986), which showed elevated civilian suicide rates for draft-eligible men. Among Gulf War veterans, a large and growing health concern stems from a collection of symptoms with no specific identifiable cause known as Gulf War syndrome. The question of whether military service is indeed the root cause of these symptoms continues to be debated, but they are usually presumed to be service-connected and therefore covered by VDC 1

The civilian re-entry experiences of each veteran cohort are in many ways unique, but there are some striking similarities. The debate over Gulf War syndrome echoes a similar controversy surrounding the rise in disability claims by Vietnam veterans-a rise that accelerated in the late 1990s and continues today. Until very recently, claims by Vietnam veterans were the source of most VDC claims growth. After 2002, this growth is partly attributable to the Veterans Benefits Administration's designation of diabetes as a service-

\footnotetext{
${ }^{1}$ Key studies of this question include Research Advisory Committe on Gulf War Veterans' Illnesses (2008) and Medical Research Council (2003). See also Iversen, Chalder, and Wessely (2007) for a review.
} 
related disability linked to the herbicide Agent Orange (Autor and Duggan, 2008) 2 Perhaps surprisingly, however, much recent claims growth is due to new PTSD claims by Vietnam veterans (Rosenheck and Fontana, 2007). The recent growth in Vietnam veterans' disability claims makes the long-term health consequences of Vietnam-era service an important contemporary policy concern.

An assessment of the link between Vietnam-era military service and long-term disability also contributes to a broader understanding of the likely health and social insurance costs of other wars. The Vietnam War lasted longer and was much more costly in terms of fatality and injury rates than more recent conflicts. Consistent with this, Vietnam veterans are much more likely to receive the maximum VDC benefit than any other cohort. We might therefore expect the health and social insurance consequences of Vietnam-era service to provide a rough upper bound on the long-term health consequences of military service for veterans of recent wars. The experiences of veterans from earlier wars provides the best available evidence on the likely consequences of military service for more recent veterans, a point made in a recent assessment of the long-run costs of the Iraq conflict by Stiglitz and Bilmes (2008).

The purpose of this paper is to provide new evidence on the long-term health impact of Vietnam-era military service. Because employment is closely associated with health, we also look at veterans' labor force status. To solve the problem of selection bias inherent in comparisons of outcomes between veterans and nonveterans, we use the draft lottery to construct instrumental variables for Vietnam-era service. Our empirical strategy relies on the 1-in-6 sample of the 2000 U.S. Decennial Census. The 2000 Census provides an exceptionally large sample and, uniquely among large representative samples, contains the birthday information required to determine draft lottery numbers. Moreover, in addition to the usual labor force status variables, the 2000 Census long form asks respondents about disabilities along a variety of dimensions, with a distinct category for disabilities that affect work. Overall, our results show no causal effect of Vietnamera veteran status on either work-related disabilities or employment. On the other hand, we find modest effects on disabilities that census respondents describe as being unrelated to work.

An important feature of our analysis is an exploration of veteran effects that vary with veterans' predicted wages and schooling. Recently, Black, Daniel, and Sanders (2002), Autor and Duggan (2003), and Duggan, Singleton, and Song (2007) have argued that high replacement rates (i.e., the ratio of disability income to prior earnings) have made Social Security Disability Insurance (SSDI) and Supplemental Security Income (SSI) an increasingly attractive alternative to employment for low-skill men not yet old enough to retire. Motivated by the possibility of similar interactions with VDC, we look for differences in the impact of veteran status across quantiles of predicted wage levels and schooling. The results of this investigation show a strong interaction: although Vietnam veteran status does not reduce employment or raise work-related disability

\footnotetext{
${ }^{2}$ The Veterans Benefits Administration is the part of the VA that administers VDC and other benefit programs.
} 
rates for Vietnam veterans overall, estimates for veterans with low predicted earnings show a large negative effect on employment and a marked increase in disability rates (again, mostly for disabilities unrelated to work). Moreover, there is little evidence that this variation can be explained by variation in the likelihood of serving in combat or a war zone. In fact, as measured in the 1987 Survey of Veterans, the likelihood of a service-connected disability is lower for less educated Vietnam veterans. These results therefore suggest that the causal effects of Vietnam-era service on employment and disability for less educated veterans reflect something other than wartime injuries. A leading alternative explanation is the relative attractiveness of VDC for less skilled men and the work disincentives embedded in the VDC system.

The paper is organized as follows. The next section uses statistics on VDC and data from the CPS to identify health concerns for Vietnam veterans and to describe recent changes in their disability status and employment rates. Section 3 then discusses the descriptive statistics and first-stage estimates from the 2000 Census that provide a foundation for the draft-lottery-based causal analysis in Section 4 Section 3 also briefly discusses the impact of Vietnam veteran status on mortality, since this is a possible source of selection bias in our analysis. Section 4 reports overall disability and employment effects and effects by predicted wage and schooling group. These results show important differences in effects across skill groups. Section 5 discusses the link between schooling and variables related to combat or war-theatre exposure and interprets the other findings in the paper. Finally, Section 6 concludes.

\section{$2 \quad$ VDC and Health in the Vietnam Cohort}

Veterans disability compensation (VDC) is determined by the combined disability rating (CDR), which is a function of the diagnoses for which VDC is awarded. Multiple disabilities are aggregated to produce the CDR. Veterans with a zero percent CDR get no monthly payment but are eligible to use the VA health care system. The largest awards go to veterans deemed to be 100 percent disabled. Veterans with a single disability rated at 60 percent or more, or a combined rating of 70 percent or more plus a single disability rated at 40 percent or more, can receive an Individual Unemployability (IU) benefit if the Veterans Benefits Administration determines that they cannot work by virtue of their disabilities. An IU determination generates payments at the 100 percent CDR level. As noted by Autor and Duggan (2008), the IU contingency generates a substantial implicit tax on the earnings of VDC awardees ${ }^{3}$

Our descriptive analysis focuses initially on VDC award and diagnosis data for the period 1999-2005

\footnotetext{
${ }^{3}$ In fiscal 2004, VDC award amounts ranged from about $\$ 100$ per month for veterans with a 10 percent CDR to almost $\$ 2,300$ per month for veterans with a 100 percent CDR (VA Office of the Inspector General, 2005). There is a much larger increase in benefits in the step from 90 to 100 percent CDR than at other steps. VDC benefits are not subject to federal income or payroll taxes and have usually kept pace with inflation. Appendix II of U.S. General Accountability Office (2006) estimates that an IU determinations adds about $\$ 348,000$ to the lifetime present value of VDC payments for a 45 year old man with a 60 percent schedular CDR.
} 
because this is a time when the Vietnam-era VDC beneficiary population was growing and changing in important ways. The top panel of Table 1 shows that in fiscal year 2005, over 900,000 Vietnam veterans were receiving VDC, up sharply from about 736,000 in 1999 (this can be compared to a Vietnam-era population of 8 million veterans, of whom about 3 million served in Vietnam or nearby). The number of disabling conditions for which Vietnam veterans received VDC also increased, from 2.76 to about 3.

In fiscal year 2005, the most widely compensated disability among Vietnam veterans was diabetes, with almost 180,000 recipients. This can be seen in the lower panels of Table 1, which lists the most common diagnoses in 2005 and the number of recipients under these diagnoses for 1999, 2001, 2003, and 2005. Diabetes was recognized as a service-related disability beginning in fiscal year 2002, in response to evidence of a possible link with exposure to the Agent Orange herbicide used by US forces during the Vietnam War. The growth in diabetes claims from zero in 2001 to many thousands in 2003 is not a reflection of new cases of diabetes, but rather reflects the fact that diabetes was a newly recognized service-related condition.

The most prevalent condition for which Vietnam veterans received compensation from 1999 to 2003 is PTSD, with about 91,000 claimants in 1999 and 143,000 in 2003. PTSD has long been a health concern for Vietnam veterans; the incidence of PTSD among Vietnam-era veterans is much larger than that for veterans of the Korean War, WWII, and the Gulf War. Perhaps surprisingly, however, the number of Vietnam-era PTSD claimants doubled between 1999 and 2005, long after the war ended. Although the recent increase in PTSD claims is sometimes attributed to the psychological impact of post-September 11th conflicts, Table 1 shows a marked increase between 1999 and 2001 (data for 2001 are from July), and a dramatic jump between fiscal 2001 and fiscal 2003, before the wars in Afghanistan and Iraq had begun to generate large numbers of casualties. Moreover, an analysis of veterans' use of PTSD treatment services in the 6 months before and after the September 11 attacks failed to uncover a short-term increase in the number of veterans seeking treatment (Rosenheck and Fontana, 2007).

The increase in PTSD among Vietnam veterans has been the subject of a number of government studies, motivated by the question of whether this increase reflects a true deterioration in health or a change in VDC eligibility screening standards and diagnostic criteria (see, e.g., VA Office of the Inspector General, 2005 and Institute of Medicine and National Research Council, 2007). A related concern is the growing proportion of PTSD beneficiaries designated IU, which increased from 14 percent in 1999 to almost 30 percent in 2006. Over one-third of IU beneficiaries in 2006 had PTSD as either a primary or secondary diagnosis (U.S. General Accountability Office, 2006) $!^{4}$

\footnotetext{
${ }^{4}$ This statistic is from Tables 5-9 and page 150 in Institute of Medicine and National Research Council (2007). A report by the VA Office of the Inspector General (2005) notes that there is more discretion in IU determinations than in the result of the CDR rating system. An earlier report along these same lines (U.S. General Accounting Office, 1987) recommended that IU determinations be subject to an evaluation by the VA's vocational services division, but this has yet to be implemented.
} 
Evidence for a regulatory or administrative explanation of the growth in the number of Vietnam veterans receiving VDC comes in part from state variation in average VDC payments. Specifically, a major contributor to cross-state differences in VDC awards appears to be variation in the likelihood that otherwise similar cases are designated 100 percent disabled as a result of IU and/or PTSD (VA Office of the Inspector General, 2005). Along the same lines, the General Accountability Office found that the number of IU beneficiaries was increased by the fact that, beginning in 1999, the Veterans Benefits Administration no longer required IU recipients to submit any kind of paperwork to maintain their IU status (U.S. General Accountability Office, 2006) 5 Moreover, around this same time, the Veterans Benefits Administration began to presume IU eligibility in some cases where veterans would previously have been required to actively file an IU claim (Cooper, 2005).

\subsection{VDC and Health Trends in the CPS}

A longer view of trends in Vietnam veterans' disability status appears in Figure 1, which shows the average amount and incidence of VA-source income. These data come from the Current Population Survey (CPS) and are described in the data appendix. The sample includes Vietnam-era and Korean-era cohorts over the period 1988-2005. Changes in VA-source income are mostly due to changes in VDC, since the Vietnam-era GI Bill expired in 1989. Figure 1 shows a marked increase in the average VA income of Vietnam veterans in the late 1990s, with a further and even sharper increase in 2004. At the same time, VA income levels were fairly flat for Korean-era veterans. As shown in Panel B, the likelihood that a Vietnam veteran received any VA income also jumped in the late 1990s, though this series is noisier than the average income series. The notion that increases in the likelihood of receiving VA income come mainly from changes in VDC receipt is supported by Panel C, which shows the probability of VDC receipt for the same period. This figure closely parallels the plot in Panel $\mathrm{B}^{6}$

Direct measures of self-reported disability rates and a measure of poor health, plotted in panels A and B of Figure 2, also increased in the late 1990s, both in absolute terms and relative to the trend among non-veterans. This increase may reflect a deterioration in the health of Vietnam veterans, but the sharpness of the break suggests that policy or regulatory changes may also play a role. Consistent with the regulatory hypothesis, Duggan, Rosenheck, and Singleton (2006) conclude that modest changes in medical eligibility criteria for federal disability programs can have a substantial impact on program enrollment. Regulatory changes may in turn influence self-reports of health if these measures are at least in part endogenous in the sense that they are caused by program use (a point made by Bound and Waidmann (1992) regarding social

\footnotetext{
${ }^{5}$ This order was rescinded in 2005 (Philpott, 2005).

${ }^{6}$ Data for the figures in this subsection are described in the appendix.
} 
security disability programs). In the CPS, there is a further mechanical link between disability income and disability assessment since the CPS disability question is a screener for questions about disability income.

As we might expect given the growing importance of IU claims in the overall VDC caseload, Panel A of Figure 3 shows that the employment rate of Vietnam veterans also dipped in the late 1990s, relative to the nonveteran trend. Though employment rates should fall as the Vietnam cohort ages, the figure shows a sharp dip relative to non-veterans the same age, after a period in which veteran and non-veteran employment rates had moved roughly in parallel. Panel B of Figure 3 shows that this relative decline is associated with a decline in self-reported health: the fraction of Vietnam veterans reporting that they quit a job or retired for health reasons ticked up sharply in 1998, and eventually pulled away from the same measure for non-veterans in the cohort. Following a brief review of related work, our main empirical analysis attempts to determine whether a causal effect of Vietnam-era military service on health can explain the relative deterioration in Vietnam veterans' self-reported health and employment rates.

\subsection{Related Work on Military Service and Health}

The question of how military service affects civilian health is of long-standing concern to veterans and policy-makers. As noted in the introduction, one of the most controversial issues in the health arena is the proper clinical response to Gulf War Syndrome (Iversen, Chalder, and Wessely, 2007). The growth in PTSD diagnoses among Vietnam veterans has been similarly controversial (Rosenheck and Fontana, 2007). Perhaps not surprisingly, given the numbers of men involved and the unique features of each era, the subject of military service and health has generated a large literature covering each service era back to WWII. A comprehensive review of these literatures is beyond the scope of our paper, but it's worth emphasizing the importance of selection bias in this context. This selection problem is highlighted by Seltzer and Jablon (1974), which shows that WWII veterans live longer than non-veterans born in the same years, primarily due to lower death rates from conditions that would have made them ineligible for service.

A number of earlier studies use instrumental variables in an effort to eliminate selection bias in estimates of the health effects of military service, as we do here. Bedard and Deschenes (2006) use cohort-dummy instruments to show that military service during World War II and the Korean conflict led to higher mortality from smoking-related causes, apparently because soldiers had access to free or subsidized cigarettes. On the other hand, using draft lottery instruments, Eisenberg and Rowe (2008) find no evidence of a lasting increase in smoking by Vietnam veterans (who did not get as large a cigarette subsidy as WWII veterans). The pioneering study by Hearst, Newman, and Hulley (1986) presents evidence for excess suicide and motor vehicle death rates among draft-eligible men. Excess mortality from these causes might be due to PTSD. 
But a re-analysis of the HNH data by Angrist, Imbens, and Rubin (1996) is less conclusive. Similarly, also using draft-lottery instruments, Dobkin and Shabani (2006) found no clear link between Vietnam-era service and a range of health outcomes measured in the National Health Interview Survey 7

\section{Census Data and the Draft-Lottery First-Stage}

\subsection{The 2000 Census 1-in-6 File}

The 2000 long-form census sample includes approximately one-sixth of U.S. households 8 For the purposes of this study, we created an extract from this sample consisting of U.S.-born men residing in the 50 States and the District of Columbia, born between 1948 and 1952. The cohorts of 19-year-olds at risk of conscription in the draft lotteries were born from 1950-52. Men born in 1948 and 1949 were also affected by the 1970 lottery, so our extract includes these two birth years as well. The estimation sample contains more than 1.14 million whites and about 155,000 nonwhites.

Roughly 31 percent of men born 1948 to 1952 served in the Vietnam era and about 44 percent were draft-eligible. The average age in the cohort is 49 . These and other descriptive statistics appear in Table 2, which reports means by veteran status and race (means for whites appear in Panel A and means for nonwhites appear in Panel B). Many men report having some kind of disability-about 20 percent of whites and a third of nonwhites. The proportions of whites and nonwhites with a disability related to work are 12 percent and 21 percent, while the proportion reporting other disabilities-not related to work-is 7 percent for whites and 12 percent for nonwhites. The work and non-work disability variables defined here are mutually exclusive, so the overall disability rate is the sum of the two rates.

White veterans have somewhat higher disability rates than non-veterans, while disability rates differ little by veteran status for nonwhites 9 Table 2 also shows that both white and nonwhite veterans are much more likely to report having income in a category that includes VDC. This is coded from an other income question that asks about sources of income received regularly such as veterans' (VA) payments, unemployment compensation, child support, or alimony. Since our all-male sample probably has no income

\footnotetext{
${ }^{7}$ Other draft lottery studies include Goldberg, Richards, Andserson, and Rodin (1991), who found no evidence of increased alcohol consumption among draft-eligible men and Hearst, Buehler, Newman, and Rutherford (1991), who found no increase in AIDS among draft-eligible men, although many Vietnam veterans stationed overseas were thought to have experimented with intravenous drugs.

${ }^{8}$ The 1-in- 6 long form sample is the basis for the publicly available PUMS files. These files, documented in US Census Bureau (2005), are simple random samples drawn from the 1-in-6 file, though the 1-in-6 file is not a simple random sample from the census sampling frame. Rather, the Census Bureau reduces the sampling rate in more densely populated areas. Adjustment for variation in sampling rates is made here by using the weighting variables that are included in the long-form file. These weights adjust for non-response and for non-random sampling, and are designed to match external population totals by age, race, sex and Hispanic origin. In practice, weighting matters little for our results.

${ }^{9}$ The work-related disability questions asks: Because of a physical, mental, or emotional condition lasting 6 months or more, does this person have any difficulty working at a job or business? The complete set of 2000 Census disability questions appears in the data appendix.
} 
from child support or alimony, and employment rates differ little by veteran status for whites and are higher for nonwhite veterans, the other income differential by veteran status is most likely due to VDC 10 In our sample, about 11 percent of white veterans have other income, a sharp contrast to the 3.7 percent of nonveterans who have this sort of income. Among nonwhites, 14 percent of veterans and 5.2 percent of nonveterans have other income.

The same panel in Table 2 gives statistics on veterans and nonveterans with Social Security income as measured by two variables, one for Supplemental Security Income (SSI), and one for Social Security Income excluding SSI. Since Vietnam-era cohorts are too young to have retired, and are unlikely to qualify for benefits under the means-tested SSI program, their Social Security income is mostly from Social Security Disability Insurance (SSDI). The proportion of veterans and nonveterans with Social Security income other than SSI is about 3.5 percent for whites and 6 percent for nonwhites, while the proportions receiving SSI are 1.3 percent for white veterans and 1.9 percent for white nonveterans. Nonwhite veterans are also less likely to receive SSI than nonwhite nonveterans (2.9 percent compared to 5.1 percent). Finally, we constructed an indicator for men who receive any federal transfers-either other income, Social Security income, or SSI. Not surprisingly, given the other income differential, both white and nonwhite veterans are much more likely to have federal transfer income of some sort 11

Table 2 also reports statistics for the specific types of disabilities identified in the census. The incidence of each type of disability is slightly higher for white veterans than for white nonveterans, while the difference in specific disability rates by veteran status is small for nonwhites. Among veterans, the most commonly reported disability is related to mobility (identified in a question asking about going outside the home alone to shop or visit a doctor's office). The second most common disability is associated with restricted physical activities such as walking, climbing stairs, reaching, lifting, or carrying. Mental disabilities are recorded in response to a question about difficulty learning, remembering, or concentrating. This is the third most common type of impairment.

Finally, the table shows descriptive statistics for two labor force status variables that might be related to self-reported disability status, not working (one minus employment) and not in the labor force. White veterans and non-veterans are about equally likely to be working or in the labor force. Among nonwhites, veterans work more.

\footnotetext{
${ }^{10}$ Income from military disability pensions received directly from the defense department is most likely captured by another census variable that asks about retirement, survivor, or disability pensions excluding Social Security. The other income variable might also include payments received under the GI Bill, but few veterans in our cohort were likely to have still been active in GI Bill supported training. Vietnam-era GI Bill eligibility expired in 1989. The 2000 Census income questions used in our study appear in the data appendix.

${ }^{11}$ Eligible claimants can receive both VDC and SSDI benefits without any reduction from either program; see Autor and Duggan (2008). In 2005, about 61 percent of VDC claimants with an IU rating received SSDI (Christensen, McMahon, Schaefer, Jaditz, and Harris, 2007). Few veterans receive SSI because SSI is means tested and because most veterans have a work history that qualifies them for the more generous SSDI program.
} 


\subsection{The Draft-Lottery First Stage}

The first draft lottery, held in December 1969, affected men born in 1944-50 who were at risk of conscription in 1970, while subsequent draft lotteries involved 19-year-olds only. Men born in 1951 were at risk of conscription in 1971 and men born in 1952 were at risk of conscription in 1972. Men born in 1953 were assigned lottery numbers in 1972, but there were no draft calls in 1973. Although men as old as 26 could have been drafted as a result of the 1970 lottery, the risk of conscription for all cohorts affected by a lottery was limited to a single year.

Each lottery was associated with a draft-eligibility ceiling or cut-off. Men with an RSN below the ceiling were draft-eligible while men with an RSN above the ceiling were draft-exempt. The draft-eligibility ceiling was 195 in the 1970 lottery, 125 in the 1971 lottery, and 95 in the 1972 lottery. Draft eligibility is highly correlated with Vietnam-era veteran status, but the link is far from deterministic. Many men with draft lottery numbers below the ceiling were able to avoid conscription through an occupational or educational deferment, or because of poor health or low test scores, while many with lottery numbers above the ceiling volunteered for service. Throughout the Vietnam era (1964-1975), most soldiers were volunteers.

In the sample of men born 1948-52, the effect of draft eligibility on Vietnam-era veteran status is .112 for whites and .072 for nonwhites. These and other draft-eligibility effects are reported in the first rows of Table 3 (Panel A for whites and Panel B for nonwhites). Draft-eligibility effects for men born 1944-47 (not reported here) are small so we omit these cohorts.

Our primary IV strategy uses a draft-eligibility dummy as an instrument for veteran status. However, in an effort to produce more efficient 2SLS estimates by exploiting within-eligibility changes in the probability of enlistment, we also work with an instrument set constructed from five lottery-number groups and interactions of these groups with year of birth (an instrument set we call $5 z x$ ). The first column in each panel of Table 3 report estimates of the lottery-group first stage in pooled samples ${ }^{12}$ For example, column 1 shows that men born 1948-52 with RSNs up to 95 were .128 more likely to serve than men with RSNs above 230 (the reference group). The next group, with RSNs 96-125, was .082 more likely to serve than the reference group; the next group was .058 more likely to serve; the next group after that was .044 more likely to serve; and the last group with RSNs 196-230 was .0059 more likely to serve. All of these first-stage effects are precisely estimated and significantly different from zero. As with the draft-eligibility effects, estimates of lottery group effects are consistently smaller for nonwhites than for whites. $F$-statistics in the pooled 1948-52 sample range from 134 for nonwhites to nearly 2300 for whites. The $5 z x$ first stage appears in columns 2-6 of Table 3. Partial $F$-statistics for the marginal contribution of $5 z x$ in a model that includes lottery-group main effects

\footnotetext{
${ }^{12}$ The estimates in Table 3 and the second-stage estimates that follow control for year of birth, state of birth, and month of birth.
} 
are on the order of 150 for whites and 10 for nonwhites 13

\subsection{Mortality and Survivor Bias in the Census Sample}

As a preliminary step, we looked for under-representation of draft-eligible men in the census sample. This analysis is motivated by the possibility that draft-eligible men were more likely to have been killed in wartime and because the link between Vietnam-era service and civilian mortality is the focus of the Hearst, Newman, and Hulley (1986) draft-lottery study of the long-term consequences of Vietnam-era service. Following the mortality investigation, which generates little evidence of an impact of Vietnam-era service on mortality, we look at the effects of Vietnam-era service on self-reported disability rates and labor force status.

Mortality effects are of interest both as an important health outcome and because excess mortality among draft-eligible men may induce selection bias in samples of survivors. The two most likely channels for excess mortality among draft-eligible men are war-related deaths and elevated post-service mortality. The latter may be due to physical injury, PTSD, or other long-term consequences of military service, such as an increased likelihood of cigarette smoking (as found by Bedard and Deschenes (2006) for World War II veterans). The excess deaths in the Hearst, Newman and Hulley (1986) study are due to suicide and motor-vehicle accidents, both causes that have been linked to PTSD.

Roughly 47,000 men died as a result of hostile action in the Vietnam Era (1964-75) while 8.7 million personnel served in the military during this period for an overall casualty rate of about half a percent. Overall casualty rates among Vietnam-era veterans were low, in part because less than half of active duty personnel served in Indochina, and because many of the men who did served in positions not exposed to combat. Although casualty rates among draftees were higher than the overall Vietnam era death rate, draftees accounted for a minority of combat deaths. It is also noteworthy that over 80 percent of combat deaths occurred before $1970{ }^{14}$ It therefore seems unlikely that war-related deaths have a large effect on the composition of the sample used in our study.

As a simple check on the possibility of mortality-related selection bias, we compared the actual and expected numbers of draft-eligible men in the 2000 Census by race and year of birth. The expected ratio was computed using monthly birth totals for males by race (Vital Statistics Division, 1948-1955), assuming birthdays (and hence lottery numbers) are uniformly distributed within a month. On the whole, draft-eligible men are represented in the census sample almost exactly as predicted, assuming a uniform distribution of

\footnotetext{
${ }^{13}$ A larger instrument set with dummies for RSN 1-30 and RSN 31-60 adds little to the precision obtained with 5zx. See Angrist and Chen (2008) for more on the draft lottery first stage.

${ }^{14}$ Service and casualty statistics in this paragraph are from Table 583 in the 2000 Statistical Abstract, available on-line at http://www.census.gov/prod/2001pubs/statab/sec11.pdf. Data on casualties by year are available from the national archives: http://www.archives.gov/research/vietnam-war/casualty-statistics.html\#year. Statistics on service in Indochina and exposure to combat are from Hearst, Newman, and Hulley (1986).
} 
lottery numbers within a month. Among whites, the predicted proportion eligible is .407, while the empirical proportion eligible is .405. Among nonwhites, the empirical proportion eligible is slightly more than predicted, .408 versus .405 .

Comparisons by single year of birth for white men born 1948-53, reported in appendix Table A1, show draft-eligible men slightly over-represented in three cohorts and slightly under-represented in the remaining three cohorts (one of these is the 1953 cohort, with no draftees). Only two cohort-specific differences for whites are significant, and all are small. Two out of six cohort-specific contrasts are significant for nonwhites, with slightly more eligibles in the sample than predicted for nonwhites born in 1950 and 1952. Given the size and sign of this set of comparisons, it seems unlikely that differential mortality by draft-eligibility status had a substantial effect on the composition of the 2000 Census sample. Equally important, these results weigh against the view that Vietnam-era service led to elevated civilian mortality.

\section{Results}

\subsection{Effects on Disability, Transfer Income, and Work}

Our main focus is on the effects of Vietnam-era service on self-reported disability status, disability-related transfers, and labor force status, all denoted by $Y_{i}$. The empirical framework for these estimates is the equation:

$$
Y_{i}=X_{i}^{\prime} \gamma_{0}+\beta_{0} V E T_{i}+\varepsilon_{i}
$$

where $X_{i}$ is a vector of controls for state, year and month of birth, and $V E T_{i}$ indicates Vietnam-era veteran status. We construct OLS and 2SLS estimates of this equation, the latter using the first stages reported in Table 3. As noted in the introduction, veterans may have suffered long-term combat injuries, either physically or as a result of PTSD. Many Vietnam veterans have also been concerned about exposure to the Agent Orange defoliant used by American forces. The loss of earnings associated with Vietnam-era conscription for white veterans (documented in Angrist, 1990) may have also been debilitating. These health effects should turn up in higher rates of disability for veterans, as captured by census self-reports. In addition, veterans may be more likely to describe themselves as disabled as a consequence of qualification for VDC and/or SSDI. This sort of endogenous disability reporting is discussed by Bound and Waidmann (1992), and Benitez-Silva, Buchinsky, Chan, Cheidvasser, and Rust (2000), among others. Finally, poor health and transfer income may directly effect employment, though each for different reasons, as we discuss further below.

The 2SLS estimates of effects on disability outcomes in Table 4 suggest that Vietnam-era conscription 
induced a small increase in self-reported disability rates among whites. The estimated effects, reported in columns 3-4, range from .012-.014 and are only marginally significant. These effects come from an increase in non-work-related disabilities; the estimated effects on work-related disability rates are nearly zero. There is little evidence of an increase in disability rates for nonwhites, though the 2SLS estimates for nonwhite men, mostly negative, are imprecise. It's also worth noting that the OLS estimates show increased disability rates for whites, while those for nonwhites show a decrease. While the sign pattern of the OLS estimates is consistent with that of the 2SLS estimates, OLS estimates are especially hard to interpret in this context, since men with disabilities are typically precluded from military service.

In contrast with the modest estimated impacts on overall disability rates, Table 4 shows a marked increase in the likelihood that (both white and nonwhite) veterans receive other income (mostly VDC). The 2SLS estimates here are around .04, which can be compared with a mean proportion receiving other income of .06-.08. At the same time, there is little evidence that Vietnam-era military service raised the proportion of men receiving income from Social Security (as noted above, Social Security income in our sample is mostly SSDI). The estimated effects on Social Security income are close to zero for whites, and negative and not significantly different from zero for nonwhites. The estimated effects on an indicator for having any federal transfers are generally similar to the effects on an indicator for other income, reflecting the absence of an overall effect on Social Security income and SSI (results for the latter are not shown in the table).

The largest and most consistent result coming out of an analysis of effects on specific disabilities is an increase in the likelihood of a vision or hearing-related problem. These effects, reported in panel C of Table 4, range from .011 for whites to .039 for nonwhites, and both are statistically significant at conventional levels. This increase might reflect an increased incidence of hearing loss or tinnitus among veterans. On the other hand, Vietnam-era service does not appear to have worsened mental health, at least, not as reflected in the rate at which men report difficulties learning, remembering, or concentrating. This is surprising given the large numbers of Vietnam veterans receiving VDC for PTSD and the fact that such difficulties are recognized PTSD symptoms (Institute of Medicine and National Research Council, 2007).

Although, the increased receipt of other (VDC) income documented in Table 4 is partly a mechanical phenomenon due to the fact that only veterans are eligible for VDC, the estimates showing higher non-workrelated disability rates for whites may reflect a negative causal impact of military service on health. But the pattern of disability effects does not seem consistent with an interpretation of the increase in disability transfers as the downstream consequence of poor veteran health. First, even if we ignore the work/nonwork distinction, the effects of military service on non-work-related disability rates are too small to explain the increase in disability-related transfers. Second, the effects on work-related disability are nearly zero. Finally, the modest disability effects in Table 4 do not appear to have translated into lower employment 
rates or reduced labor force participation, as would usually be expected for disabled workers.

The next section further explores the link between Vietnam-era military service and disability, focusing on how this link varies with measures of earnings potential.

\subsection{Interactions with Predicted Wages and Schooling}

The empirical literature on the unintended economic consequences of disability insurance has two themes. The first is that such programs increase the likelihood of early retirement. For example, Bound and Waidmann (1992) and Stapleton and Burkhauser (2003) present evidence suggesting that disability insurance contributed significantly to the drop in labor force participation of near-elderly men over the second half of the twentieth century. A second strand of this literature argues that disability insurance has become increasingly attractive for (non-elderly) low-skilled men because declining real wages for the less skilled have meant a rise in disability insurance replacement rates. In particular, Autor and Duggan (2003) find a close link between enrollment in SSDI and SSI and regional variation in wage levels. Black, Daniel, and Sanders (2002) similarly show that disability insurance take-up rates are highly sensitive to regional variation in labor demand.

As with Social Security disability programs, VDC may provide an attractive alternative to employment for low-wage men even if their disabling conditions are not serious enough to prevent or limit paid employment. In support of this view, Duggan, Rosenheck, and Singleton (2006) show that enrollment in the VDC program seems highly sensitive to small changes in eligibility criteria and in unemployment rates. Moreover, paralleling the incentives created by SSDI and SSI, VDC should reduce work for low-wage men through both income and substitution effects. Substitution effects arise because many veterans are awarded benefits at the 100 percent level on the basis of an IU determination that depends in part on low earnings.

We explore the link between earnings potential and disability outcomes for Vietnam veterans by looking for variation in the causal effects of veteran-status across skill groups. If causal effects on VDC take-up rates and self-reported disability status are driven primarily by deteriorating health, we should not expect these effects to be larger for men in the lowest skill groups, unless low-skill men were also more likely to have suffered wartime injuries. On the other hand, if VDC is used primarily as an alternative to work for those with low earnings potential, we should see a strong gradient in the effects of veteran status.

Our interacted models use predicted wages and a schooling variable to define skill groups. The predicted wage is the fitted value from a regression of nonveterans' weekly wages on state of birth and education interactions, controlling for year of birth. Descriptive statistics for subsamples classified by predicted wage appear in columns 4-7 of Table 2. Not surprisingly, these statistics show that men with a lower predicted 
wage are much more likely to be disabled and have reduced labor force attachment. In addition, we report results from an alternative specification using interactions classified by four schooling groups only. This provides a robustness check and generates a scheme that can be matched to our analysis of combat exposure by schooling group, described below. As it turns out, the two classification schemes for interacted models produce similar results 15

The empirical framework for models with interactions is

$$
Y_{i}=\sum_{j=1}^{4}\left(\alpha_{j} D_{i j}+\beta_{j} D_{i j} V E T_{i}\right)+X_{i}^{\prime} \gamma+\varepsilon_{i}
$$

where the variables $D_{i 1}$ to $D_{i 4}$ are either dummy variables that indicate men with a predicted wage below the 10th percentile, between the 10th and 25th percentile, between the 25 th and 75 th percentile, and above the 75th percentile, or indicators for four schooling groups (high school dropout, high school graduate, some college [but less than a bachelor's degree], and college graduate). The $D_{i j} \times V E T_{i}$ terms are treated as endogenous and a set of four $D_{i j} \times E L I G_{i}$ terms are used as excluded instruments in 2SLS estimation of a just-identified model (Table 4 suggests little precision is gained in over-identified models). As before, the vector of covariates, $X_{i}$, contains dummies for year, month, and state of birth. The coefficients of interest are $\beta_{1}$ to $\beta_{4}$, the estimated causal effect of Vietnam veteran status on men in each predicted wage or schooling group 16

The resulting 2SLS estimates appear in Table 5. Column 1 in Panel A shows that for white men in the lowest wage group, the effect of Vietnam veteran status on the probability of reporting any disability is .118 (the mean disability rate in this group is .4 , as shown in Table 1 ). There are also much smaller, though still marginally significant, effects of .037 and .02 on white men with wages in the next two quantile groups, but no effect on men with high earnings potential. An almost identical pattern arises when predicted wage groups are replaced by schooling groups, as can be seen in Panel B.

The overall disability effects are decomposed into effects on work-related and non-work-related disabilities in columns 2 and 3 of Table 5 . Consistent with a similar breakdown in the full sample, the first row in each panel of Table 5 shows that the large veteran effect on any disability for low-skilled men is due mostly to

\footnotetext{
${ }^{15}$ The sample for the predicted wage regressions consists of male US-born nonveterans born 1948-52. The dependent variable is the weekly wage and the explanatory variables are a full set of state of birth by education-group effects plus year of birth main effects. The education groups are: high school dropout, high school graduate, some college, and college graduate, as described in the appendix. Wage prediction regressions were run separately for whites and nonwhites.

${ }^{16}$ The schooling classification scheme also provide a check on selection bias from the possible endogeneity of schooling. Specifically, 2SLS estimates using the draft lottery (reported in Angrist and Chen, 2008) show that Vietnam-era military service increased the likelihood of college attendance but had little effect on schooling at the high school level or below. Therefore, draft-lottery estimation of veteran effects conditional on high school graduation status is unaffected by any posttreatment selection bias that might contaminate contrasts by college graduation status. This in turn means that the difference in treatment effects between high school dropouts and the other three groups is not subject to to bias from conditioning on an outcome variable.
} 
an effect on non-work-related disabilities, with no significant effect on work-related disabilities in any group (though the effect on work-related disabilities for men with wages in the lowest group is still substantial). The estimated veteran impacts on both non-work and work-related disabilities are essentially zero for the highest skill group.

Effects on transfer income are generally somewhat larger than those on non-work-related disabilities, as can be seen in columns 4-6. Moreover, while veterans at all predicted wage levels are estimated to be more likely to have other income (VDC), the largest effect is again for men with the lowest earnings potential. The estimated effects on other income in the low skill groups are .073 using predicted wages and .08 using schooling groups. The effect of veteran status on the likelihood of receiving Social Security income (SSDI) is smaller than that on other income but still significant for men in the lowest skill groups. This suggests that many of the men who leave the labor force to receive VDC also qualify for and receive SSDI (as argued by Autor and Duggan, 2008).

On the other hand, the results for any federal transfers indicate that SSDI (and to a lesser extent, SSI) is a partial substitute for VDC. This is apparent from the fact that effects on the aggregate transfer category are larger than the effects on any single component. For example, veterans in the lowest skill group are estimated to be about 12 percentage points more likely to be receiving federal transfers, while those in the next lowest group are a little over 5 percentage points more likely to be receiving a transfer. Disabled veterans may begin receiving SSDI while they are waiting (or trying) to qualify for VDC or vice versa; the two programs have separate and independent disability determination procedures. Although SSDI is not designed to be especially attractive to veterans, all SSDI veterans who apply are required to submit their military discharge papers (form DD-214). In practice, military service increases SSDI benefit levels and the likelihood of SSDI qualification for men with weak labor force attachment because time in the military generates additional earnings credits in addition to base pay 17

The last set of results in Table 5 is for the impact on employment and labor force participation. These estimates, reported in columns 7 and 8, show a marked decrease in employment and labor force participation among men in the lowest skill groups, with more muted effects in the middle of the predicted wage or schooling distribution, and no effect for men at the top of these distributions. The parallel between the variation in employment effects across skill groups and the pattern of effects on disability and transfer income is striking. Although the employment and labor force participation effects are too large to be explained by the estimated effects on work-related disabilities reported in column 2, they come out below the effects on aggregate transfers, a point we return to in the next section.

Finally, Table 6 looks at effects on specific disability types. Here, too, the estimated impact of Vietnam-

\footnotetext{
${ }^{17}$ See, e.g., the pamphlet Social Security and Military Service, available at http://www.ssa.gov/pubs/10017.pdf.
} 
era service is largest at the low end of the predicted wage or schooling distribution, with no significant effects at the high end. The largest impact at the low end is on physical disabilities, a category that probably includes most muscular and skeletal problems (e.g., related to knees or back). There appear to be smaller effects on physical disabilities in the second-lowest skill group. The second largest set of veteran effects relates to mental disabilities, for which there are also significant impacts in the second lowest skill group. Vision and hearing problems also appear to have been aggravated by military service among men at the low end of the skill distribution. Thus, within skill groups, the impact of military service on specific limitations seems broadly consistent with the diagnoses most prevalent among VDC claimants ${ }^{18}$

\section{Interpreting the Impact of Vietnam-era Service Across Skill Groups}

A natural question raised by the results in Table 5 is whether Vietnam-era service impacts on disability, transfer income, and employment for low-skill men can be accounted for by differences across skill groups in exposure to combat or the risk of service-related injury. For example, to be diagnosed with PTSD, a veteran must establish that he was exposed to traumatic events of an extreme nature (VA Office of the Inspector General, 2005, p. 46). We therefore ask whether less-educated men were more likely to be exposed to combat or war or to have suffered a service-connected disability. We explore this question using the 1987 Survey of Veterans (known as the SOV-III since it was the third in a series of veteran surveys). The SOV-III interviewed veterans (excluding those still on active duty) in CPS outgoing rotation groups from April 1986 through January 1987. The survey covered roughly two thousand Vietnam veterans and collected information on veterans' service experiences and health. Most relevant for us, the SOV-III included questions about service location, exposure to combat, and a direct assessment of service-connected disabilities. The data appendix describes the criteria used to select our extract, which is a subset of the sample analyzed in Angrist (1993). Because the results in Tables 4 and 5 show significant effects only for whites, we focus on white men in the SOV-III.

Our empirical analysis is structured by an equation linking combat or war exposure and service-connected disabilities with schooling dummies similar to those in Panel B of Table 519 Among all white Vietnam veterans in our SOV-III extract (a sample that includes men born 1943-57), 40 percent report having served in the Vietnam War theatre (Vietnam, Laos, or Cambodia), 36 percent report exposure to combat, 46 percent

\footnotetext{
${ }^{18}$ We also looked at models for log wages as in Angrist and Chen (2008). The estimated effects on log wages, both overall and within skill groups are essentially zero.

${ }^{19}$ Definitions of SOV-III schooling groups appear in the data appendix. Schooling group dummies describe education at the time of the SOV-III survey. The covariates in these regressions consist of 5-year cohort dummies.
} 
report exposure to combat or war, and 6.1 percent report a service-connected disability 20 To increase the sample size, our extract includes men born 1943-57, but the descriptive statistics for this sample are broadly similar to those for the draft lottery cohorts (men born 1948-52), as can be seen in the first rows of Panels A and B in Table 7. One exception, however, is the low incidence of service-connected disabilities for high school dropouts in the draft lottery subsample, probably a difference due to sampling variation in the smaller sample. We therefore report results for the full sample of Vietnam veterans as well as the draft lottery subsample.

The regression estimates in columns 1-4 of Table 7 are coefficients on dummy variables for high school graduates, men with some college, and college graduates, relative to a high school dropout reference group. The dependent variables are indicators for men who were stationed in the Vietnam War theatre, were exposed to combat, or were exposed to combat or war. These estimates show little difference in the likelihood of exposure or service-related disability across schooling groups. For example, the mean rate of exposure to combat among high school dropouts was about .33 in the full Vietnam veteran sample (shown in Panel A, column 2), while the combat exposure rates were only 1 percentage point less for men with some college or a college degree.

Because the largest effects of Vietnam veteran status on disability and employment appear among high school dropouts, the relationship between high school dropout status and exposure to war or combat is of special interest. Estimates of this relationship are reported in columns 5-7 of Table 7, which show the effects of having a high school diploma on the likelihood Vietnam veterans served in the war theatre, were exposed to combat, or were exposed to combat or war. The estimated differences by schooling group are small for each dependent variable and none are significantly different from zero.

The muted relationship between education and exposure to war or combat does not support the notion that less educated veterans were more likely to suffer war-related trauma or injury. For more evidence on this point, we compare rates of service-connected injuries across schooling groups. (The SOV-III asks specifically about service-connected injuries while the disability variables in the 2000 census are more general.) Columns 4 and 8 in Panel A of Table 7 show that there is no significant difference in the likelihood of a service-related disability across schooling groups in the full sample of Vietnam veterans. The comparison across schooling groups using data from the draft lottery cohorts (reported in Panel B) shows high school dropouts were less likely to report a service-related injury than were more educated veterans. Thus, the results in Table 7 suggest the effects of Vietnam veteran status on self-reported disability and employment among less educated

\footnotetext{
${ }^{20}$ Respondents are coded as having been exposed to combat if they responded yes to a question asking whether they were in or exposed to combat; respondents are coded as having been exposed to combat or war if they indicated that they were either exposed to combat or were stationed in war zone; respondents with a service-connected disability are those who indicated they have been notified by the VA that they are eligible for payment for a service-connected medical condition or disability.
} 
men in the 2000 Census cannot be explained by a higher risk of exposure to war or service-connected injury in the low education group.

The results in Table 5 also point away from health per se as the primary explanation for lower employment rates among Vietnam veterans with low earnings potential. As noted earlier, the effects on work-related disabilities are too small (on the order of 4-5 percentage points) to account for employment reductions ranging from 7-12 percentage points (depending on the outcome and skill group definition). It therefore seems likely that part of the explanation for service-induced increases in disability rates among the low-skilled is an ex post validation of VDC or SSDI eligibility, a status administratively bound up with employment. Specifically, a veteran who qualifies for a federal disability insurance program may be more likely to identify himself as disabled, even if his disability does not limit work. The strong effect of Vietnam era veteran status on aggregate transfer income, reported in column 6 of Table 5, seems like the leading proximate cause for the negative effect of veteran status on employment and labor force participation rates among low skilled men.

\section{Conclusions}

Our estimates of the causal effects of Vietnam-era military service on disability rates, transfer income, and employment paint a complicated picture. On one hand, there appears to have been only a small serviceinduced increase in overall disability rates among white veterans, and an insignificant decrease among nonwhites. Moreover, the increase among whites comes entirely from disabilities judged by census respondents to be unrelated to work. On the other hand, an analysis of effects by skill groups, using either predicted wages or schooling, shows a sizeable effect on disability among the least skilled white veterans, with some smaller but still significant effects in the lower-middle of the skill distribution. There are also large negative effects on employment in the lowest skill groups.

Did the least skilled suffer the most serious and lasting health consequences of Vietnam-era service? Our analysis points away from this interpretation. First, less educated men were not more likely to serve in the Vietnam War theatre, to be exposed to combat or war, or to have reported a service-connected disability in 1987. In addition, the estimated effects of Vietnam-era veteran status on work-related disabilities are too small to explain the estimated effects on employment and labor force participation. A case can therefore be made for disability insurance as a primary causal agent driving these results. Veterans who get VDC (or SSDI), especially those who are (or aspire to be) classified as "individually unemployable", are probably more likely to define themselves as disabled and less likely to work. This seems to be a special concern for Vietnam-era PTSD claims; data from 2005 show that roughly one-third of PTSD claimants are designated 
IU and that IU claimants are concentrated in the Vietnam cohort (Christensen, et al, 2007, Figures 58-59).

Our results have important implications for veterans compensation policy. The number of Vietnam-era VDC beneficiaries grew rapidly in the late 1990s, growth that accelerated in the early part of this century and has not yet leveled off. This imposes a growing burden on a system that must serve new cohorts of veterans from the Gulf War, Afghanistan, and Iraq. The results reported here suggest the growth in Vietnam-era disability claims (and hence costs) are not only a manifestation of the health consequences of the Vietnam war, but also a reflection of the incentives embedded in our disability insurance system for veterans.

The results reported here also raise questions about widely publicized projections of the disability costs likely to come out of current conflicts. Specifically, Stiglitz and Bilmes (2008, pp. 82-83) note that a large number of VDC claims in this most recent cohort are for PTSD and that PTSD is an especially expensive diagnosis associated with high program costs and large earnings losses. But the costliness of PTSD claims comes in large part from the link with IU and the consequent increase in VDC benefits. Case reviews in VA Office of the Inspector General (2005) show that mental health visits declined by 82 percent after an IU rating decision, and that many granted an IU determination stop seeking treatment for mental health entirely, though health care visits for other conditions are unchanged. Likewise, our results indicate that the employment consequences of PTSD may have as much to do with incentives as with a medical inability to work, at least in many cases. The complicated links between military service and variables related to health show that the disability-related costs of conflict are driven by policy and regulatory choices, as well as the battlefield consequences of war.

\section{References}

Angrist, Joshua D. (1990): "Lifetime Earnings and the Vietnam Era Draft Lottery: Evidence from Social Security Administrative Records," American Economic Review, 80, 313-335.

(1993): "The Effect of Veterans Benefits on Education and Earnings," Industrial and Labor Relations Review, 46, 637-652.

Angrist, Joshua D., and Stacey H. Chen (2008): "Long-Term Economic Consequences of Vietnam-Era Conscription: Schooling, Experience and Earnings," IZA Discussion Paper No. 3628.

Angrist, Joshua D., Guido Imbens, and Donald B. Rubin (1996): "Identification of Causal Effects Using Instrumental Variables," Journal of the American Statistical Association, 91, 444-472.

Autor, David H., and Mark G. Duggan (2003): "The Rise In The Disability Rolls And The Decline In Unemployment," Quarterly Journal of Economics, 118, 157-205. 
(2008): "The Effect of Transfer Income on Labor Force Participation and Enrollment in Federal Benefits Programs: Evidence from the Veterans Disability Compensation Program," Unpublished manuscript.

Bedard, Kelly, and Olivier Deschenes (2006): "The Long-Term Impact of Military Service on Health: Evidence fron World War II and Korean War Veterans," American Economic Review, 96.

Benitez-Silva, Hugo, Moshe Buchinsky, Hiu Man Chan, Sofia Cheidvasser, and John Rust (2000): "How Large is the Bias in Self-Reported Disability?," NBER Working Paper No. 7526.

Black, Dan, Kermit Daniel, and Seth Sanders (2002): "The Impact of Economic Conditions on Participation in Disability Programs: Evidence from the Coal Boom and Bust," The American Economic Review, 92, 27-50.

Bound, John, and Timothy Waidmann (1992): "Disability Transfers, Self-Reported Health, and the Labor Force Attachment of Older Men: Evidence from the Historical Record," The Quarterly Journal of Economics, 107, 1393-1419.

Christensen, Eric, Joyce McMahon, Elizabeth Schaefer, Ted Jaditz, and Dan Harris (2007): "Final Report for the Veterans' Disability Benefits Commission: Compensation, Survey Results, and Selected Topics," Alexandria, Virginia: CNA Corporation.

Cooper, Daniel L. (2005): "Statement Before the Senate Committee on Veterans' Affairs, October 27, 2005," Available at http://www.va.gov/OCA/testimony/svac/05102720.asp.

Dobkin, C., and R. Shabani (2006): "The Long Term health Effects of Military Service: Evidence from the National Health Interview Survey and the Vietnam Era Draft Lottery," University of California at Santa Cruz, Department of Economics, mimeo.

Duggan, Mark, Robert Rosenheck, and Perry Singleton (2006): "Federal Policy and the Rise in Disability Enrollment: Evidence for the VA's Disability Compensation Program," NBER Working Paper 12323.

Duggan, Mark, Perry Singleton, and Jae Song (2007): "Aching to Retire? The Rise in the Full Retirement Age and its Impact on the Social Security Disability Rolls," Journal of Public Economics, 91, $1327-1350$.

Eisenberg, Daniel, and Brian Rowe (2008): "The Effects of Smoking in Young Adulthood on Smoking and Health Later in Life: Evidence Based on the Vietnam Era Draft Lottery," US Census Bureau Center for Economic Studies Paper No. CES-WP-08-35. 
Goldberg, J., M. Richards, R. Andserson, and M. Rodin (1991): "Alcohol Consumption in Men Exposed to the Military Draft Lottery: A Natural Experiment," Journal of Substance Abuse, 3, 307-313.

Hearst, N., T. Buehler, T. Newman, and G. Rutherford (1991): "The Draft Lottery and AIDS: Evidence Against Increased Intravenous Drug Use by Vietnam Veterans," American Journal of Epidemiology, $134,522-525$.

Hearst, N, TB Newman, and SB Hulley (1986): "Delayed Effects of the Military Draft on Mortality. A Randomized Natural Experiment," New England Journal of Medicine, 314, 620-624.

Institute of Medicine and National Research Council (2007): PTSD Compensation and Military Service. The National Academies Press, Washington, DC.

Iversen, Amy, Trudie Chalder, and Simon Wessely (2007): "Gulf War Illness: Lessons from Medically Unexplained Symptoms," Clinical Psychology Review, 27, 842 - 854.

Medical Research Council (2003): "MRC Review of Research into UK Gulf Veterans' Illnesses," London: The Medical Research Council.

Philpotт, Tom (2005): “Too many 'IU' vets?," Stars and Stripes, Pacific edition, Thursday, May 19, 2005. Accessed from http://www.stripes.com/article.asp?section=104\&article=29174 on December 15, 2008.

Research Advisory Committe on Gulf War Veterans' Illnesses (2008): "Gulf War Illness and the Health of Gulf War Veterans: Scientific Findings and Recommendations," Washington, D.C.: U.S. Government Printing Office.

Rosenheck, Robert A., and Alan F. Fontana (2007): "Recent Trends In VA Treatment Of PostTraumatic Stress Disorder And Other Mental Disorders," Health Affairs, 26, 1720-1727.

Seltzer, Carl C., and Seymour Jablon (1974): "Effects of Selection on Mortality," American Journal of Epidemiology, 100.

Social Security Administration (2009): "Social Security and Military Service," SSA Publication No. 05-10017, Available at http://www.ssa.gov/pubs/10017.pdf.

Stapleton, David C., and Richard V. Burkhauser (eds.) (2003): The Decline in Employment of People with Disabilities: A Policy Puzzle. W.E. Upjohn Institute for Employment Research, Kalamazoo, MI.

Stiglitz, Joseph, and Linda Bilmes (2008): The Three Trillion Dollar War. Allen Lane. 
U.S. Bureau of the Census (2000): "Statistical Abstract of the United States, 2000," Washington, DC: U.S. Government Printing Office.

(2006): "Statistical Abstract of the United States, 2006," Washington, DC: U.S. Government Printing Office.

U.S. General Accountability Office (2006): "Veterans' Disability Benefits: VA Should Improve Its Management of Individual Unemployability Benefits by Strengthening Criteria, Guidance, and Procedures," GAO Report GAO-06-309.

U.S. General Accounting Office (1987): "Improving the Integrity of VA's Unemployability Compensation Program," General Accounting Office Report HRD-87-62.

VA Office of the Inspector General (2005): "Review of State Variances in VA Disability Compensation Payments," VA Office of Inspector General Report No. 05-00765-137, Washington, D.C.

Veterans Benefits Administration (2007): “Annual Benefits Report for Fiscal Year 2006,” Washington, D.C.: Veterans Benefits Administration.

Vital Statistics Division, Bureau of the Census (1948-1955): "Vital Statistics of the United States," Washington, D.C.: United States Government Printing Office.

\section{DATA APPENDIX}

\section{Health and Disability Data in the CPS}

Figures 1-3 were constructed using data from the 1990-2006 CPS March Demographic Supplements. All data were downloaded from the Minnesota Population Center's Integrated Public Use Microdata Series (IPUMS), accessible at www.ipums.org. Year of birth was imputed assuming men were born after the survey date. We categorized Vietnam veterans as all men born between 1944-54 who served during the Vietnam era, as reported in the variable VETLAST, which reports an individual's most recent period of service. Active duty servicemen were excluded. Korean-era veterans were identified the same way, except we used the 1929-1934 birth cohort. Nonveterans were classified based on the variable VETSTAT.

The disability-related income variables used in Figure 1 uses the variable INCVET and a dummy for men who received veterans' disability compensation (GOTVDISA), both in 2005 dollars.. INCVET captures any income from the VA, including service-related disability payments (VDC), non-disability pension payments, 
and educational allowances. GOTVDISA information is collected only for respondents who received veterans' payments during the previous calendar year, and it indicates whether respondents received VDC.

Figure 2 was constructed from the variable DISABWRK, which codes the response to a question about disabilities that limit or prevent work. Men with fair or poor health were identified using the variable HEALTH, which gives self-reported health status. This variable is available beginning in 1996.

The employment measure used in Panel A of Figure 3 is based on the CPS variable EMPSTAT, which codes as working men at work, with a job not at work, or in the armed forces. The share quitting or retiring for health reasons in Panel B is based on the CPS variable QUITSICK, which identifies respondents who said that they had ever retired or left a job for health reasons.

All plots show weighted means collapsed by year using sampling weights (PERWT) and including imputed values. Because income amounts refer to the previous year in the March CPS, Figure 1 runs from 1989-2005. Disability and health are measured at the time of the survey, so Panel A of Figure 2 runs from 1990-2006 and Panel B from 1996-2006.

\section{Census Disability Questions}

We constructed disability variables from responses to the following questions:

16. Does this person have any of the following long-lasting conditions:

a. Blindness, deafness, or a severe vision or hearing impairment? (Yes, No)

b. A condition that substantially limits one or more basic physical activities such as walking, climbing stairs, reaching, lifting, or carrying? (Yes, No)

17. Because of a physical, mental, or emotional condition lasting 6 months or more, does this person have any difficulty in doing any of the following activities:

a. Learning, remembering, or concentrating? (Yes, No)

b. Dressing, bathing, or getting around inside the home? (Yes, No)

c. (Answer if this person is 16 YEARS OLD OR OVER.) Going outside the home alone to shop or visit a doctor's office? (Yes, No)

d. (Answer if this person is 16 YEARS OLD OR OVER.) Working at a job or business? (Yes, No)

A respondent was coded as having a work related disability if he or she answered "Yes" to 17(d). He was coded as having a non-work related disability if he answered "No" to $17(\mathrm{~d})$, but yes to any of 16(a), 16(b), or 
17(a)-17(c). The variable "any disability" was defined as having either a work-related or non-work-related disability. Specific disabilities were coded as follows: Vision or hearing (yes to 16(a)); Physical (yes to 16(b)); Mental (yes to 17(a)); Self-care (yes to 17(b)); Mobility (yes to 17(c)).

\section{Census VA and Social Security Income Questions}

The 2000 Census has one multi-part question that collects information on income by source. We use these parts of question 31, Income in 1999:

d. Social Security or Railroad Retirement

e. Supplemental Security Income (SSI)

h. Any other sources of income received regularly such as Veterans' (VA) payments, unemployment compensation, child support, or alimony - Do NOT include lump-sum payments such as money from an inheritance or sale of a home.

The response to 31(h) is used to code an indicator for Other Income (mostly VDC); the response to 31(d) is used to code an indicator for Social Security Income (mostly SSDI); our dummy for any federal transfers indicates individuals with an amount in either 31(d), 31(e), or 31(h).

\section{Survey of Veterans (SOV-III) Sample Selection}

The analysis of the SOV-III in Section 5 starts with the extract of 3,337 Vietnam and later-era veterans used by Angrist (1993). These data are available at http://econ-www.mit.edu/faculty/angrist/data/ang1993. For confidentiality reasons, age data in the SOV-III are bracketed in 5-year intervals. The sample used in Table 7, Panel A is arrived at by restricting to white males with bracketed ages between 30 and 44 who served during the Vietnam era as indicated by their response to Question 4(c). Finally, the five observations with missing education (coded N/A) are deleted to arrive at a sample size of 1893. The sample in Panel B is further restricted to recoded ages between 35 and 39 for a sample size of 724 .

\section{Schooling Group Definitions in the 2000 Census and SOV-III}

The analysis in Section 4.2 defines four schooling groups using the highest level of school completed (question 9 in the census). The four census schooling groups are:

1. High school dropout: the highest level completed is at most 12th grade, no diploma (response code less than or equal to 9 ) 
2. High school graduate: the highest level completed is high school graduate or GED (response code equal to 10$)$

3. Some college: the highest level completed is greater than high school graduate but less than a Bachelor's degree (response codes 11-13)

4. College graduate: the highest level completed is greater than or equal to a Bachelor's degree (response codes 14 and up)

The four schooling groups in the Survey of Veterans (analyzed in Section 5 ) are based on respondents' answers to questions 15(b) (highest degree before service), 15(c) (highest grade completed), and 15(d) (highest degree received):

1. High school dropout: the highest level completed is at most 11 (response code 5 or less in question $15(\mathrm{c}))$

2. High school graduate: the highest level completed is 12 or a vocational program (response code 6 or 7 in question $15(\mathrm{c}))$

3. Some college: the highest level completed includes at least one year of college but less than a Bachelor's degree (response code 8 or more in question 15(c), but a code of less than 2 in questions 15(b) and $15(\mathrm{~d}))$

4. College graduate: the highest level completed is at least a Bachelor's degree (response code 2 or more in question $15(\mathrm{~b})$ or $15(\mathrm{~d}))$ 
Table 1: Veterans disability compensation claims

\begin{tabular}{|c|c|c|c|}
\hline Diagnosis & Year & $\begin{array}{l}\text { Disabilities per } \\
\text { Veteran }\end{array}$ & $\begin{array}{l}\text { Veterans Receiving } \\
\text { Compensation }\end{array}$ \\
\hline \multicolumn{4}{|l|}{ All disabilities } \\
\hline & 1999 & 2.76 & 735,627 \\
\hline & 2001 & 2.77 & 749,554 \\
\hline & 2003 & 2.88 & 848,156 \\
\hline & 2005 & 3.00 & 916,220 \\
\hline \multicolumn{4}{|l|}{ Diabetes } \\
\hline & 1999 & & - \\
\hline & 2001 & & - \\
\hline & 2003 & & 135,011 \\
\hline & 2005 & & 190,199 \\
\hline \multicolumn{4}{|l|}{ PTSD } \\
\hline & 1999 & & 90,695 \\
\hline & 2001 & & 106,809 \\
\hline & 2003 & & 142,876 \\
\hline & 2005 & & 179,737 \\
\hline \multicolumn{4}{|c|}{ Hearing (loss of acuity) } \\
\hline & 1999 & & 50,184 \\
\hline & 2001 & & 60,753 \\
\hline & 2003 & & 95,931 \\
\hline & 2005 & & 129,323 \\
\hline \multicolumn{4}{|l|}{ Scars } \\
\hline & 1999 & & 127,023 \\
\hline & 2001 & & 125,939 \\
\hline & 2003 & & 125,534 \\
\hline & 2005 & & 121,850 \\
\hline \multicolumn{4}{|c|}{$\begin{array}{l}\text { Generalized Musculoskeletal } \\
\text { Conditions }\end{array}$} \\
\hline & 1999 & & 82,446 \\
\hline & 2001 & & 80,586 \\
\hline & 2003 & & 78,413 \\
\hline & 2005 & & 78,270 \\
\hline \multicolumn{4}{|l|}{ Hypertension } \\
\hline & 1999 & & 56,231 \\
\hline & 2001 & & 55,545 \\
\hline & 2003 & & 66,084 \\
\hline & 2005 & & 72,169 \\
\hline \multicolumn{4}{|c|}{ Arthritis (due to trauma) } \\
\hline & 1999 & & 48,263 \\
\hline & 2001 & & 53,332 \\
\hline & 2003 & & 62,821 \\
\hline & 2005 & & 69,034 \\
\hline \multicolumn{4}{|l|}{ Knee impairment } \\
\hline & 1999 & & 67,836 \\
\hline & 2001 & & 66,335 \\
\hline & 2003 & & 65,026 \\
\hline & 2005 & & 62,713 \\
\hline
\end{tabular}

Notes: This table reports the number of veterans receiving VDC in total and for specific disabilities. The listed diagnoses are the top 10 conditions in 2005 , except for tinnitus (which is often diagnosed with loss of hearing acuity) and degenerative arthritis (which is not in the top 10 before 2005). Diabetes recognized as a service-related impairment in 2002.

Source: Veterans Benefits Administration Annual Reports for 1999, 2001, 2003, and 2005. 


\begin{tabular}{|c|c|c|c|c|c|c|c|}
\hline & \multirow[b]{2}{*}{$\begin{array}{l}\text { All } \\
(1)\end{array}$} & \multirow[b]{2}{*}{$\begin{array}{c}\text { Vietnam veteran } \\
(2)\end{array}$} & \multirow[b]{2}{*}{$\begin{array}{l}\text { Non-veteran } \\
\text { (3) }\end{array}$} & \multicolumn{4}{|c|}{ Wage index percentile } \\
\hline & & & & $\begin{array}{l}<10 \\
(4)\end{array}$ & $\begin{array}{c}10-25 \\
(5)\end{array}$ & $\begin{array}{c}25-75 \\
(6)\end{array}$ & $\begin{array}{l}>75 \\
(7)\end{array}$ \\
\hline \multicolumn{8}{|c|}{ A. Whites } \\
\hline Veteran status (served in Vietnam Era) & 0.305 & 1.000 & 0.000 & 0.246 & 0.328 & 0.350 & 0.234 \\
\hline Age & 49.2 & 49.6 & 49 & 49.1 & 48.9 & 49.2 & 49.3 \\
\hline Any disability & 0.198 & 0.217 & 0.190 & 0.401 & 0.279 & 0.193 & 0.116 \\
\hline Work disability & 0.124 & 0.114 & 0.120 & 0.253 & 0.181 & 0.120 & 0.072 \\
\hline Non-work disability & 0.074 & 0.083 & 0.070 & 0.148 & 0.099 & 0.073 & 0.044 \\
\hline \multicolumn{8}{|c|}{ ii. Transfer income } \\
\hline Other income (mostly VDC) $>0$ & 0.059 & 0.109 & 0.037 & 0.068 & 0.067 & 0.064 & 0.045 \\
\hline SSA income excluding SSI (mostly SSDI) $>0$ & 0.035 & 0.036 & 0.034 & 0.102 & 0.056 & 0.031 & 0.014 \\
\hline \multicolumn{8}{|c|}{ iii. Specific disability types } \\
\hline $\begin{array}{l}\text { Mental (difficulty learning, remembering, c } \\
\text { concentrating; }\end{array}$ & 0.045 & 0.049 & 0.044 & 0.141 & 0.071 & 0.039 & 0.019 \\
\hline $\begin{array}{l}\text { Vision or hearing (blindness, deafness, or : } \\
\text { severe vision or hearing impairmen }\end{array}$ & 0.038 & 0.043 & 0.036 & 0.080 & 0.052 & 0.037 & 0.022 \\
\hline $\begin{array}{l}\text { Physical (limitation to physical activities suc } \\
\text { as walking, climbing stairs, reaching, lifting } \\
\text { or carrying; }\end{array}$ & 0.052 & 0.054 & 0.052 & 0.203 & 0.127 & 0.083 & 0.043 \\
\hline $\begin{array}{l}\text { Mobility (difficulty going outside the hom } \\
\text { alone) }\end{array}$ & 0.086 & 0.101 & 0.080 & 0.140 & 0.084 & 0.047 & 0.024 \\
\hline $\begin{array}{l}\text { Self-care (difficulty dressing, bathing, o } \\
\text { getting around inside the home) }\end{array}$ & 0.022 & 0.022 & 0.022 & 0.065 & 0.034 & 0.019 & 0.010 \\
\hline \multicolumn{8}{|c|}{ iv. Labor market variables } \\
\hline Not working & 0.145 & 0.154 & 0.141 & 0.342 & 0.219 & 0.135 & 0.076 \\
\hline \multicolumn{8}{|c|}{ B. Nonwhites } \\
\hline Draft eligibility (by RSN) & 0.440 & 0.520 & 0.406 & 0.430 & 0.421 & 0.447 & 0.447 \\
\hline Veteran status (served in Vietnam Era) & 0.293 & 1.000 & 0.000 & 0.153 & 0.228 & 0.349 & 0.296 \\
\hline Age & 49.2 & 49.5 & 49 & 49.0 & 49.0 & 49.2 & 49.3 \\
\hline \multicolumn{8}{|c|}{ i. Disability variables } \\
\hline Any disability & 0.332 & 0.326 & 0.334 & 0.447 & 0.391 & 0.314 & 0.201 \\
\hline Work disability & 0.212 & 0.205 & 0.215 & 0.273 & 0.247 & 0.203 & 0.136 \\
\hline Non-work disability & 0.120 & 0.120 & 0.120 & 0.174 & 0.145 & 0.111 & 0.066 \\
\hline \multicolumn{8}{|c|}{ ii. Transfer income } \\
\hline Other income (mostly VDC) $>0$ & 0.078 & 0.140 & 0.052 & 0.067 & 0.072 & 0.084 & 0.070 \\
\hline SSA income excluding SSI (mostly SSDI) $>0$ & 0.060 & 0.056 & 0.062 & 0.094 & 0.077 & 0.054 & 0.027 \\
\hline $\mathrm{SSI}>0$ & 0.044 & 0.029 & 0.051 & 0.086 & 0.063 & 0.035 & 0.016 \\
\hline Any Federal transfer income $>0$ & 0.163 & 0.198 & 0.148 & 0.219 & 0.188 & 0.155 & 0.102 \\
\hline \multicolumn{8}{|c|}{ iii. Specific disability types } \\
\hline $\begin{array}{l}\text { Mental (difficulty learning, remembering, c } \\
\text { concentrating; }\end{array}$ & 0.076 & 0.072 & 0.077 & 0.135 & 0.101 & 0.062 & 0.034 \\
\hline $\begin{array}{l}\text { Vision or hearing (blindness, deafness, or } \\
\text { severe vision or hearing impairmen }\end{array}$ & 0.048 & 0.047 & 0.049 & 0.070 & 0.060 & 0.044 & 0.029 \\
\hline $\begin{array}{l}\text { Physical (limitation to physical activities suc } \\
\text { as walking, climbing stairs, reaching, lifting } \\
\text { or carrying) }\end{array}$ & 0.122 & 0.112 & 0.126 & 0.204 & 0.167 & 0.128 & 0.076 \\
\hline $\begin{array}{l}\text { Mobility (difficulty going outside the hom } \\
\text { alone) }\end{array}$ & 0.139 & 0.145 & 0.136 & 0.173 & 0.152 & 0.113 & 0.063 \\
\hline $\begin{array}{l}\text { Self-care (difficulty dressing, bathing, o } \\
\text { getting around inside the home) }\end{array}$ & 0.042 & 0.036 & 0.044 & 0.068 & 0.055 & 0.036 & 0.021 \\
\hline \multicolumn{8}{|c|}{ iv. Labor market variables } \\
\hline Employment & 0.662 & 0.705 & 0.644 & 0.510 & 0.433 & 0.304 & 0.168 \\
\hline
\end{tabular}


Table 3. First-stage estimates by race and year of birth

\begin{tabular}{|c|c|c|c|c|c|c|}
\hline & Pooled cohorts & & By & le year & irth & \\
\hline & $\begin{array}{c}1948-52 \\
(1) \\
\end{array}$ & $\begin{array}{c}1948 \\
(2)\end{array}$ & $\begin{array}{c}1949 \\
(3)\end{array}$ & $\begin{array}{c}1950 \\
(4)\end{array}$ & $\begin{array}{c}1951 \\
(5)\end{array}$ & $\begin{array}{c}1952 \\
(6)\end{array}$ \\
\hline & & Whites & & & & \\
\hline Draft-eligibility effect & $\begin{array}{l}.112 \\
(.001)\end{array}$ & $\begin{array}{l}.058 \\
(.001)\end{array}$ & $\begin{array}{l}.074 \\
(.003)\end{array}$ & $\begin{array}{l}.133 \\
(.002)\end{array}$ & $\begin{array}{l}.138 \\
(.002)\end{array}$ & $\begin{array}{l}.168 \\
(.002)\end{array}$ \\
\hline RSN effects (5zx): & & & & & & \\
\hline RSN 1-95 & $\begin{array}{l}.128 \\
(.001)\end{array}$ & $\begin{array}{l}.065 \\
(.003)\end{array}$ & $\begin{array}{l}.088 \\
(.003)\end{array}$ & $\begin{array}{l}.154 \\
(.003)\end{array}$ & $\begin{array}{l}.155 \\
(.003)\end{array}$ & $\begin{array}{l}.173 \\
(.003)\end{array}$ \\
\hline RSN 96-125 & $\begin{array}{l}.082 \\
(.002)\end{array}$ & $\begin{array}{l}.060 \\
(.005)\end{array}$ & $\begin{array}{l}.077 \\
(.005)\end{array}$ & $\begin{array}{l}.131 \\
(.004)\end{array}$ & $\begin{array}{l}.128 \\
(.004)\end{array}$ & $\begin{array}{l}.023 \\
(.003)\end{array}$ \\
\hline RSN 126-160 & $\begin{array}{l}.058 \\
(.002)\end{array}$ & $\begin{array}{l}.054 \\
(.004)\end{array}$ & $\begin{array}{l}.061 \\
(.004)\end{array}$ & $\begin{array}{c}.126 \\
(.004)\end{array}$ & $\begin{array}{l}.050 \\
(.004)\end{array}$ & $\begin{array}{l}.0084 \\
(.003)\end{array}$ \\
\hline RSN 161-195 & $\begin{array}{l}.044 \\
(.002)\end{array}$ & $\begin{array}{l}.044 \\
(.004)\end{array}$ & $\begin{array}{l}.054 \\
(.004)\end{array}$ & $\begin{array}{l}.102 \\
(.004)\end{array}$ & $\begin{array}{l}.024 \\
(.003)\end{array}$ & $\begin{array}{r}-.0013 \\
(.003)\end{array}$ \\
\hline RSN 196-230 & $\begin{array}{l}.0059 \\
(.002)\end{array}$ & $\begin{array}{l}.0043 \\
(.004)\end{array}$ & $\begin{array}{l}.0062 \\
(.004)\end{array}$ & $\begin{array}{l}.013 \\
(.004)\end{array}$ & $\begin{array}{r}-.0012 \\
(.003)\end{array}$ & $\begin{array}{l}.0077 \\
(.003)\end{array}$ \\
\hline F-statistics & 2294 & 111 & 202 & 731 & 861 & 1028 \\
\hline & & onwhites & & & & \\
\hline Draft-eligibility effect & $\begin{array}{c}.072 \\
(.003)\end{array}$ & $\begin{array}{l}.031 \\
(.007)\end{array}$ & $\begin{array}{l}.049 \\
(.006)\end{array}$ & $\begin{array}{l}.090 \\
(.006)\end{array}$ & $\begin{array}{l}.096 \\
(.006)\end{array}$ & $\begin{array}{l}.096 \\
(.006)\end{array}$ \\
\hline RSN effects (5zx): & & & & & & \\
\hline RSN 1-95 & $\begin{array}{l}.081 \\
(.003)\end{array}$ & $\begin{array}{l}.039 \\
(.009)\end{array}$ & $\begin{array}{c}.059 \\
(.008)\end{array}$ & $\begin{array}{l}.101 \\
(.007)\end{array}$ & $\begin{array}{l}.101 \\
(.007)\end{array}$ & $\begin{array}{l}.099 \\
(.007)\end{array}$ \\
\hline RSN 96-125 & $\begin{array}{l}.058 \\
(.005)\end{array}$ & $\begin{array}{l}.027 \\
(.013)\end{array}$ & $\begin{array}{l}.072 \\
(.012)\end{array}$ & $\begin{array}{c}.089 \\
(.011)\end{array}$ & $\begin{array}{l}.090 \\
(.011)\end{array}$ & $\begin{array}{l}.016 \\
(.009)\end{array}$ \\
\hline RSN 126-160 & $\begin{array}{l}.041 \\
(.005)\end{array}$ & $\begin{array}{l}.027 \\
(.012)\end{array}$ & $\begin{array}{l}.042 \\
(.012)\end{array}$ & $\begin{array}{l}.093 \\
(.011)\end{array}$ & $\begin{array}{l}.034 \\
(.010)\end{array}$ & $\begin{array}{l}.0052 \\
(.009)\end{array}$ \\
\hline RSN 161-195 & $\begin{array}{l}.021 \\
(.005)\end{array}$ & $\begin{array}{l}.012 \\
(.012)\end{array}$ & $\begin{array}{l}.027 \\
(.011)\end{array}$ & $\begin{array}{l}.066 \\
(.010)\end{array}$ & $\begin{array}{l}-.0047 \\
(.009)\end{array}$ & $\begin{array}{l}.0055 \\
(.009)\end{array}$ \\
\hline RSN 196-230 & $\begin{array}{l}.0007 \\
(.005)\end{array}$ & $\begin{array}{l}-.004 \\
(.012)\end{array}$ & $\begin{array}{l}.018 \\
(.011)\end{array}$ & $\begin{array}{l}.008 \\
(.010)\end{array}$ & $\begin{array}{l}-.010 \\
(.009)\end{array}$ & $\begin{array}{l}-.0055 \\
(.009)\end{array}$ \\
\hline F-statistics & 134 & 4.98 & 14.3 & 48.9 & 55.1 & 47.3 \\
\hline
\end{tabular}

Notes: This table reports draft-eligibility and RSN-group effects on the probability of veteran status. Draft-eligibility effects and RSN group effects are from separate regressions. Robust standard errors are shown in parentheses. All models include a full set of dummies for year of birth, state of birth, and month of birth. Statistics use census sample weights. 
Table 4. OLS and 2SLS estimates of effects on disability and labor force status for men born 1948-52

\begin{tabular}{|c|c|c|c|c|c|c|c|c|}
\hline \multirow[b]{3}{*}{ Dependent variable } & \multicolumn{4}{|c|}{ Whites } & \multicolumn{4}{|c|}{ Nonwhites } \\
\hline & \multirow[b]{2}{*}{$\begin{array}{c}\text { Mean } \\
(1) \\
\end{array}$} & \multirow[b]{2}{*}{$\begin{array}{l}\text { OLS } \\
(2) \\
\end{array}$} & \multicolumn{2}{|c|}{$2 S L S$} & \multirow[b]{2}{*}{$\begin{array}{l}\text { Mean } \\
(5)\end{array}$} & \multirow[b]{2}{*}{$\begin{array}{l}\text { OLS } \\
(6)\end{array}$} & \multicolumn{2}{|c|}{$2 S L S$} \\
\hline & & & $\begin{array}{l}\text { elig } \\
(3)\end{array}$ & $\begin{array}{l}5 z x \\
(4)\end{array}$ & & & $\begin{array}{l}\text { elig } \\
(7)\end{array}$ & $\begin{array}{c}5 z x \\
(8)\end{array}$ \\
\hline & \multicolumn{8}{|c|}{ A. Disability variables } \\
\hline Any disability & .198 & $\begin{array}{c}.024 \\
(.001)\end{array}$ & $\begin{array}{c}.012 \\
(.008)\end{array}$ & $\begin{array}{c}.014 \\
(.007)\end{array}$ & .332 & $\begin{array}{l}-.012 \\
(.003)\end{array}$ & $\begin{array}{l}-.061 \\
(.040)\end{array}$ & $\begin{array}{l}-.063 \\
(.036)\end{array}$ \\
\hline Work disability & .124 & $\begin{array}{l}.013 \\
(.001)\end{array}$ & $\begin{array}{l}.000 \\
(.007)\end{array}$ & $\begin{array}{l}-.001 \\
(.006)\end{array}$ & .212 & $\begin{array}{l}-.010 \\
(.003)\end{array}$ & $\begin{array}{l}-.045 \\
(.034)\end{array}$ & $\begin{array}{l}-.054 \\
(.031)\end{array}$ \\
\hline Non-work disability & .074 & $\begin{array}{c}.011 \\
(.001)\end{array}$ & $\begin{array}{c}.013 \\
(.005)\end{array}$ & $\begin{array}{l}.014 \\
(.005)\end{array}$ & .120 & $\begin{array}{l}-.001 \\
(.002)\end{array}$ & $\begin{array}{l}-.016 \\
(.028)\end{array}$ & $\begin{array}{l}-.006 \\
(.026)\end{array}$ \\
\hline \multicolumn{9}{|c|}{ B. Transfer income } \\
\hline Other income (mostly VDC) $>0$ & .059 & .072 & .042 & .040 & .078 & .087 & .034 & .040 \\
\hline & & $(.001)$ & $(.005)$ & $(.004)$ & & $(.002)$ & $(.022)$ & $(.020)$ \\
\hline SSA income (mostly SSDI) $>0$ & .035 & $\begin{array}{c}.000 \\
(.000)\end{array}$ & $\begin{array}{c}.001 \\
(.004)\end{array}$ & $\begin{array}{c}.004 \\
(.003)\end{array}$ & .060 & $\begin{array}{l}-.007 \\
(.002)\end{array}$ & $\begin{array}{l}-.027 \\
(.020)\end{array}$ & $\begin{array}{l}-.030 \\
(.018)\end{array}$ \\
\hline Any Federal transfer income $>0$ & .100 & $\begin{array}{c}.058 \\
(.001)\end{array}$ & $\begin{array}{c}.039 \\
(.006)\end{array}$ & $\begin{array}{l}.040 \\
(.005)\end{array}$ & .163 & $\begin{array}{c}.047 \\
(.002)\end{array}$ & $\begin{array}{c}.032 \\
(.031)\end{array}$ & $\begin{array}{c}.027 \\
(.028)\end{array}$ \\
\hline \multicolumn{9}{|c|}{ C. Specific disability types } \\
\hline Mental & .045 & $\begin{array}{c}.003 \\
(.001)\end{array}$ & $\begin{array}{c}.007 \\
(.004)\end{array}$ & $\begin{array}{c}.006 \\
(.004)\end{array}$ & .076 & $\begin{array}{l}-.007 \\
(.002)\end{array}$ & $\begin{array}{c}.015 \\
(.023)\end{array}$ & $\begin{array}{c}.011 \\
(.021)\end{array}$ \\
\hline Vision or hearing & .038 & $\begin{array}{c}.005 \\
(.000)\end{array}$ & $\begin{array}{c}.011 \\
(.004)\end{array}$ & $\begin{array}{c}.012 \\
(.003)\end{array}$ & .048 & $\begin{array}{l}-.003 \\
(.001)\end{array}$ & $\begin{array}{c}.039 \\
(.018)\end{array}$ & $\begin{array}{c}.036 \\
(.016)\end{array}$ \\
\hline Physical & .052 & $\begin{array}{c}.001 \\
(.001)\end{array}$ & $\begin{array}{c}.005 \\
(.005)\end{array}$ & $\begin{array}{l}.005 \\
(.004)\end{array}$ & .122 & $\begin{array}{l}-.014 \\
(.002)\end{array}$ & $\begin{array}{l}-.008 \\
(.028)\end{array}$ & $\begin{array}{l}-.008 \\
(.025)\end{array}$ \\
\hline Mobility & .086 & $\begin{array}{c}.018 \\
(.001)\end{array}$ & $\begin{array}{c}.009 \\
(.006)\end{array}$ & $\begin{array}{c}.012 \\
(.005)\end{array}$ & .139 & $\begin{array}{c}.005 \\
(.002)\end{array}$ & $\begin{array}{l}-.028 \\
(.029)\end{array}$ & $\begin{array}{l}-.030 \\
(.026)\end{array}$ \\
\hline Self-care & .022 & $\begin{array}{c}.000 \\
(.000)\end{array}$ & $\begin{array}{c}.007 \\
(.003)\end{array}$ & $\begin{array}{l}.008 \\
(.003)\end{array}$ & .042 & $\begin{array}{l}-.009 \\
(.001)\end{array}$ & $\begin{array}{c}.011 \\
(.017)\end{array}$ & $\begin{array}{l}-.001 \\
(.016)\end{array}$ \\
\hline \multicolumn{9}{|c|}{ D. Labor force status } \\
\hline Not working & .145 & $\begin{array}{c}.010 \\
(.001)\end{array}$ & $\begin{array}{c}.005 \\
(.007)\end{array}$ & $\begin{array}{c}.003 \\
(.007)\end{array}$ & .338 & $\begin{array}{l}-.063 \\
(.003)\end{array}$ & $\begin{array}{l}-.001 \\
(.040)\end{array}$ & $\begin{array}{l}-.020 \\
(.037)\end{array}$ \\
\hline Not in labor force & .118 & $\begin{array}{c}.007 \\
(.001) \\
\end{array}$ & $\begin{array}{c}.002 \\
(.007) \\
\end{array}$ & $\begin{array}{c}.002 \\
(.006) \\
\end{array}$ & .284 & $\begin{array}{l}-.057 \\
(.003) \\
\end{array}$ & $\begin{array}{c}.026 \\
(.039) \\
\end{array}$ & $\begin{array}{r}.016 \\
(.035) \\
\end{array}$ \\
\hline
\end{tabular}

Note: This table reports OLS and 2SLS estimates of the effects of Vietnam veteran status on the dependent variable listed at left. All regressions include a full set of dummies for state of birth, year of birth and month of birth. The estimates in columns 3 and 7 use a simple draft-eligibility dummy as instruments. The estimates in columns 4 and 8 use 5 RSN dummies interacted with year of birth. Robust standard errors are reported in parentheses. Estimates use census sampling weights. 
Table 5. 2SLS estimates of veteran effects by predicted wage and schooling

\begin{tabular}{|c|c|c|c|c|c|c|c|c|c|}
\hline & & \multicolumn{3}{|c|}{ Disability variables } & \multicolumn{3}{|c|}{ Transfer income } & \multicolumn{2}{|c|}{ Labor Force Status } \\
\hline & & $\begin{array}{c}\text { Any disability } \\
\text { (1) }\end{array}$ & $\begin{array}{c}\text { Work } \\
\text { disability } \\
(2)\end{array}$ & $\begin{array}{c}\text { Non-work } \\
\text { disability } \\
(3)\end{array}$ & $\begin{array}{c}\text { Other income } \\
\text { (mostly VDC) } \\
>0 \\
(4)\end{array}$ & $\begin{array}{c}\text { SSA income } \\
\text { (mostly SSDI) } \\
>0 \\
(5)\end{array}$ & $\begin{array}{c}\text { Any Federal } \\
\text { transfer } \\
\text { income }>0 \\
(6)\end{array}$ & $\begin{array}{c}\text { Not working } \\
(7)\end{array}$ & $\begin{array}{c}\text { Not in labor } \\
\text { force } \\
(8)\end{array}$ \\
\hline & & \multicolumn{8}{|c|}{ A. By wage index percentile } \\
\hline \multirow{7}{*}{$\begin{array}{l}\text { Veteran status } \\
\text { x wage index } \\
\text { percentile }\end{array}$} & $<10$ & 0.118 & 0.053 & 0.065 & 0.073 & 0.061 & 0.117 & 0.091 & 0.072 \\
\hline & & $(0.038)$ & $(0.034)$ & $(0.028)$ & $(0.019)$ & $(0.024)$ & $(0.030)$ & $(0.037)$ & $(0.035)$ \\
\hline & $10-25$ & 0.037 & 0.025 & 0.012 & 0.039 & 0.015 & 0.053 & 0.037 & 0.026 \\
\hline & $25-75$ & 0.020 & 0.002 & 0.019 & 0.045 & 0.000 & 0.041 & 0.014 & 0.012 \\
\hline & & $(0.009)$ & $(0.008)$ & $(0.006)$ & $(0.006)$ & $(0.004)$ & $(0.007)$ & $(0.008)$ & $(0.007)$ \\
\hline & $>75$ & -0.002 & -0.005 & 0.003 & 0.032 & -0.006 & 0.027 & -0.014 & -0.012 \\
\hline & & $(0.012)$ & $(0.009)$ & $(0.007)$ & $(0.007)$ & $(0.004)$ & $(0.009)$ & $(0.010)$ & $(0.009)$ \\
\hline & & \multicolumn{8}{|c|}{ B. By schooling group } \\
\hline \multirow{7}{*}{$\begin{array}{l}\text { Veteran status } \\
\text { x schooling } \\
\text { group }\end{array}$} & HS dropout & 0.105 & 0.039 & 0.066 & 0.080 & 0.084 & 0.134 & 0.116 & 0.086 \\
\hline & & $(0.050)$ & $(0.044)$ & $(0.037)$ & $(0.025)$ & $(0.032)$ & $(0.042)$ & $(0.049)$ & $(0.047)$ \\
\hline & HS grad & 0.036 & 0.018 & 0.018 & 0.033 & 0.009 & 0.036 & 0.032 & 0.027 \\
\hline & Some college & 0.026 & 0.009 & 0.017 & 0.056 & 0.002 & 0.056 & 0.014 & 0.009 \\
\hline & & $(0.011)$ & $(0.009)$ & $(0.008)$ & $(0.007)$ & $(0.005)$ & $(0.009)$ & $(0.010)$ & $(0.009)$ \\
\hline & College degree & 0.006 & -0.005 & 0.011 & 0.036 & -0.005 & 0.032 & -0.006 & -0.005 \\
\hline & & $(0.010)$ & $(0.008)$ & $(0.006)$ & $(0.006)$ & $(0.004)$ & $(0.007)$ & $(0.008)$ & $(0.007)$ \\
\hline
\end{tabular}

Notes: Panel A reports coefficients from a regression of the variable indicated in the column heading on dummies for the wage index percentile and their interactions with Vietnam veteran status, and Panel B reports coefficients from a regression of the variable indicated in the column heading on dummies for education level and their interactions with Vietnam veteran status. All regressions control for state, year, and month of birth. The wage index was computed from a regression of nonveterans' weekly wages on state of birth and education interactions, controlling for year of birth. Robust standard errors are shown in parentheses. 
Table 6. 2SLS estimates of veteran effect interactions for specific disability types

\begin{tabular}{|c|c|c|c|c|c|c|}
\hline & \multicolumn{5}{|c|}{ Disability Type: } \\
\hline & & $\begin{array}{c}\text { Mental } \\
(1)\end{array}$ & $\begin{array}{c}\text { Vision or } \\
\text { hearing } \\
(2)\end{array}$ & $\begin{array}{c}\text { Physical } \\
(3)\end{array}$ & $\begin{array}{c}\text { Mobility } \\
(4)\end{array}$ & $\begin{array}{c}\text { Self-care } \\
(5)\end{array}$ \\
\hline & & \multicolumn{5}{|c|}{ A. By wage index percentile } \\
\hline \multirow{9}{*}{$\begin{array}{l}\text { Veteran status } \\
\text { x wage index } \\
\text { percentile }\end{array}$} & $<10$ & .069 & .046 & .098 & .062 & .026 \\
\hline & & $(.027)$ & $(.021)$ & $(.031)$ & $(.027)$ & $(.019)$ \\
\hline & $10-25$ & .020 & .020 & .032 & .012 & .019 \\
\hline & & $(.009)$ & $(.008)$ & $(.012)$ & $(.010)$ & $(.007)$ \\
\hline & $25-75$ & .008 & .014 & .011 & .008 & .009 \\
\hline & & $(.005)$ & $(.004)$ & $(.006)$ & $(.005)$ & $(.003)$ \\
\hline & $>75$ & -.001 & -.001 & -.010 & -.003 & .001 \\
\hline & & $(.005)$ & $(.005)$ & $(.007)$ & $(.006)$ & $(.004)$ \\
\hline & & \multicolumn{5}{|c|}{ B. By schooling group } \\
\hline \multirow{8}{*}{$\begin{array}{l}\text { Veteran status } \\
\text { x schooling } \\
\text { group }\end{array}$} & HS dropout & .060 & .047 & .120 & .056 & .036 \\
\hline & & $(.037)$ & $(.028)$ & $(.042)$ & $(.037)$ & $(.027)$ \\
\hline & HS grad & .013 & .021 & .026 & .010 & .011 \\
\hline & & $(.006)$ & $(.006)$ & $(.009)$ & $(.007)$ & $(.005)$ \\
\hline & Some college & .012 & .010 & .015 & .011 & .013 \\
\hline & & $(.006)$ & $(.006)$ & $(.008)$ & $(.006)$ & $(.004)$ \\
\hline & College degree & & & & & \\
\hline & & $\begin{array}{l}.003 \\
(.004)\end{array}$ & $\begin{array}{l}.006 \\
(.004)\end{array}$ & $\begin{array}{l}-.006 \\
(.006)\end{array}$ & $\begin{array}{l}.002 \\
(.005)\end{array}$ & $\begin{array}{l}.002 \\
(.003)\end{array}$ \\
\hline
\end{tabular}

Notes: Panel A reports coefficients from a regression of the variable indicated in the column heading on dummies for the wage index percentile and their interactions with Vietnam veteran status, and Panel B reports coefficients from a regression of the variable indicated in the column heading on dummies for education level and their interactions with Vietnam veteran status. All regressions control for state, year, and month of birth. The wage index was computed from a regression of non-veterans' weekly wages on state of birth and education interactions, controlling for year of birth. Robust standard errors are shown in parentheses. 
Table 7. Combat and war-theater exposure by education for white Vietnam veterans

\begin{tabular}{|c|c|c|c|c|c|c|c|c|}
\hline & \multicolumn{4}{|c|}{ Schooling } & \multicolumn{4}{|c|}{ HS graduate status only } \\
\hline & $\begin{array}{c}\text { Vietnam/ Laos/ } \\
\text { Cambodia } \\
\text { (1) }\end{array}$ & $\begin{array}{c}\text { Combat } \\
(2)\end{array}$ & $\begin{array}{c}\text { Combat or } \\
\text { war } \\
(3)\end{array}$ & $\begin{array}{c}\text { Service-related } \\
\text { disability } \\
(4)\end{array}$ & $\begin{array}{c}\text { Vietnam/ Laos/ } \\
\text { Cambodia } \\
(5) \\
\end{array}$ & $\begin{array}{c}\text { Combat } \\
(6)\end{array}$ & $\begin{array}{c}\text { Combat or } \\
\text { war } \\
(7)\end{array}$ & $\begin{array}{c}\text { Service-related } \\
\text { disability } \\
(8) \\
\end{array}$ \\
\hline & \multicolumn{8}{|c|}{ A. Birth cohorts 1943-1957 $(\mathrm{N}=1893)$} \\
\hline Dependent variable mean & 0.398 & 0.360 & 0.462 & 0.061 & 0.398 & 0.360 & 0.462 & 0.061 \\
\hline Dep. var. mean for HS dropouts & 0.406 & 0.328 & 0.439 & 0.074 & 0.406 & 0.328 & 0.439 & 0.074 \\
\hline \multicolumn{9}{|l|}{ Regression estimates } \\
\hline HS graduate & $\begin{array}{c}0.021 \\
(0.063)\end{array}$ & $\begin{array}{c}0.050 \\
(0.063)\end{array}$ & $\begin{array}{c}0.054 \\
(0.065)\end{array}$ & $\begin{array}{l}-0.035 \\
(0.033)\end{array}$ & & & & \\
\hline Some college & $\begin{array}{l}-0.059 \\
(0.062)\end{array}$ & $\begin{array}{l}-0.010 \\
(0.063)\end{array}$ & $\begin{array}{l}-0.019 \\
(0.066)\end{array}$ & $\begin{array}{l}-0.002 \\
(0.035)\end{array}$ & & & & \\
\hline College graduate & $\begin{array}{l}-0.081 \\
(0.065)\end{array}$ & $\begin{array}{l}-0.010 \\
(0.066)\end{array}$ & $\begin{array}{l}-0.044 \\
(0.068)\end{array}$ & $\begin{array}{l}-0.007 \\
(0.036)\end{array}$ & & & & \\
\hline HS graduate or more & & & & & $\begin{array}{c}-0.033 \\
(0.059)\end{array}$ & $\begin{array}{c}0.014 \\
(0.060)\end{array}$ & $\begin{array}{c}0.004 \\
(0.062)\end{array}$ & $\begin{array}{c}-0.016 \\
(0.033)\end{array}$ \\
\hline$F$ test $p$-value for education vars. & 0.039 & 0.294 & 0.071 & 0.185 & 0.584 & 0.818 & 0.950 & 0.621 \\
\hline & \multicolumn{8}{|c|}{ B. Birth cohorts $1948-1952(\mathrm{~N}=724)$} \\
\hline Dependent variable mean & 0.417 & 0.371 & 0.439 & 0.053 & 0.417 & 0.371 & 0.439 & 0.053 \\
\hline Dep. var. mean for HS dropouts & 0.404 & 0.404 & 0.419 & 0.007 & 0.404 & 0.404 & 0.419 & 0.007 \\
\hline \multicolumn{9}{|l|}{ Regression estimates } \\
\hline HS graduate & $\begin{array}{c}0.072 \\
(0.108)\end{array}$ & $\begin{array}{l}-0.018 \\
(0.107)\end{array}$ & $\begin{array}{c}0.081 \\
(0.108)\end{array}$ & $\begin{array}{c}0.039 \\
(0.020)\end{array}$ & & & & \\
\hline Some college & $\begin{array}{c}0.025 \\
(0.108)\end{array}$ & $\begin{array}{l}-0.007 \\
(0.108)\end{array}$ & $\begin{array}{c}0.029 \\
(0.108)\end{array}$ & $\begin{array}{c}0.054 \\
(0.019)\end{array}$ & & & & \\
\hline College graduate & $\begin{array}{l}-0.112 \\
(0.115)\end{array}$ & $\begin{array}{l}-0.113 \\
(0.116)\end{array}$ & $\begin{array}{l}-0.100 \\
(0.116)\end{array}$ & $\begin{array}{c}0.058 \\
(0.027)\end{array}$ & & & & \\
\hline HS graduate or more & & & & & $\begin{array}{c}0.014 \\
(0.103)\end{array}$ & $\begin{array}{l}-0.035 \\
(0.103)\end{array}$ & $\begin{array}{c}0.022 \\
(0.104)\end{array}$ & $\begin{array}{c}0.049 \\
(0.014)\end{array}$ \\
\hline$F$ test $p$-value for education vars. & 0.078 & 0.461 & 0.088 & 0.004 & 0.893 & 0.736 & 0.834 & 0.000 \\
\hline
\end{tabular}


Table A1. Proportion Draft-Eligible in the 2000 Census

\begin{tabular}{|c|c|c|c|c|c|c|}
\hline & \multicolumn{3}{|c|}{ Whites } & \multicolumn{3}{|c|}{ Non-whites } \\
\hline & Theoretical & Actual & Difference & Theoretical & Actual & Difference \\
\hline \multirow{3}{*}{1948} & $(1)$ & $(2)$ & $(3)$ & $(4)$ & $(5)$ & $(6)$ \\
\hline & 0.5348 & 0.5303 & -0.0044 & 0.5358 & 0.5376 & 0.0017 \\
\hline & & $(.0012)$ & $(.0012)$ & & $(.0034)$ & $(.0034)$ \\
\hline \multirow[t]{2}{*}{1949} & 0.5358 & 0.5359 & 0.0002 & 0.5354 & 0.5371 & 0.0016 \\
\hline & & $(.0012)$ & $(.0012)$ & & $(.0032)$ & $(.0032)$ \\
\hline \multirow[t]{2}{*}{1950} & 0.5376 & 0.5384 & 0.0008 & 0.5371 & 0.5440 & 0.0069 \\
\hline & & $(.0012)$ & $(.0012)$ & & $(.0032)$ & $(.0032)$ \\
\hline \multirow[t]{2}{*}{1951} & 0.3424 & 0.3395 & -0.0030 & 0.3417 & 0.3427 & 0.0010 \\
\hline & & $(.0011)$ & $(.0011)$ & & $(.0031)$ & $(.0031)$ \\
\hline \multirow[t]{2}{*}{1952} & 0.2596 & 0.2596 & 0.0000 & 0.2583 & 0.2650 & 0.0068 \\
\hline & & $(.0010)$ & $(.0010)$ & & $(.0028)$ & $(.0028)$ \\
\hline \multirow[t]{2}{*}{1953} & 0.2604 & 0.2592 & -0.0012 & 0.2600 & 0.2653 & 0.0053 \\
\hline & & $(.0010)$ & $(.0010)$ & & $(.0028)$ & $(.0028)$ \\
\hline$F(6, \infty)$ & & & 3.74 & & & 2.48 \\
\hline
\end{tabular}

Notes: The theoretical proportion draft eligible is reported in column 1 for each cohort. Fractions appear in brackets. Columns 2-4 report the difference between this and the empirical proportion draft-eligible, with robust standard errors in parentheses. The F-statistic is for a joint test of theoretical and empirical equality for all cohorts. 


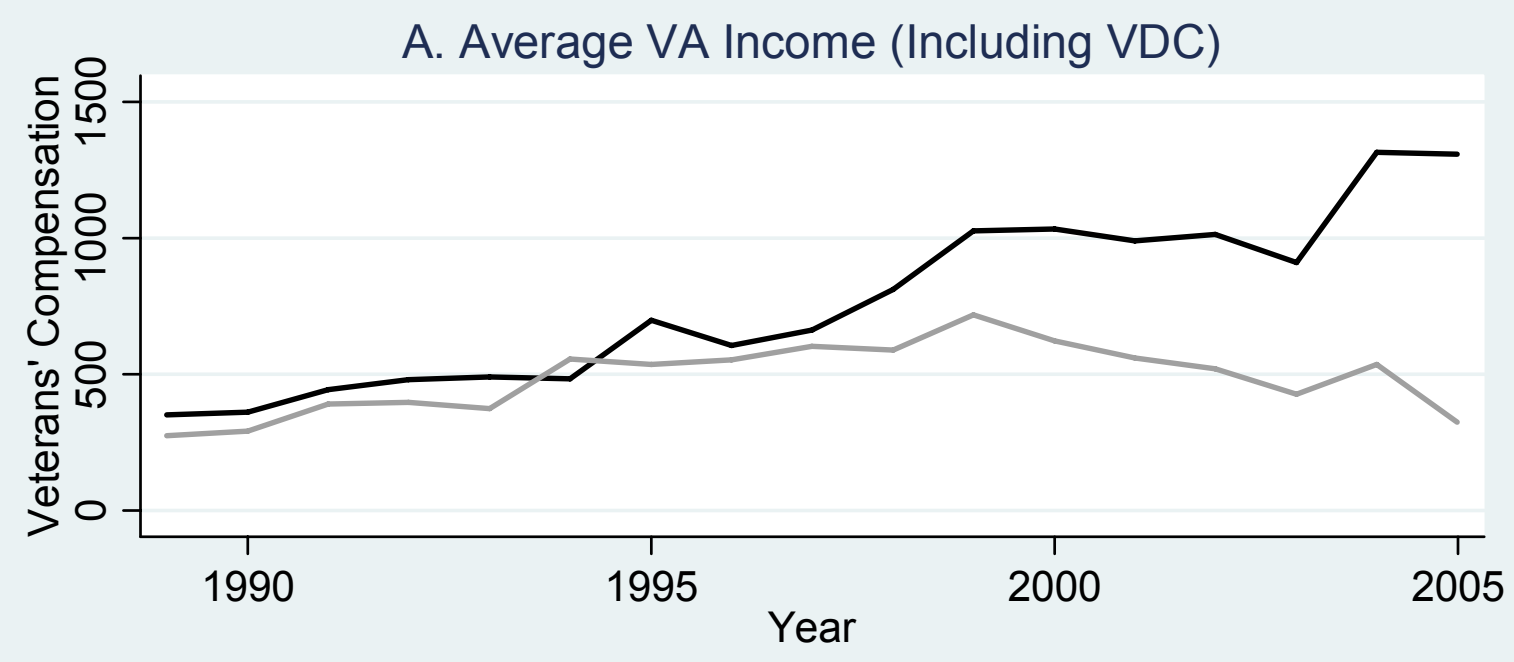

Vietnam vets, born 1944-54

Korea vets, born 1929-34

B. Share With VA Income (Including VDC)

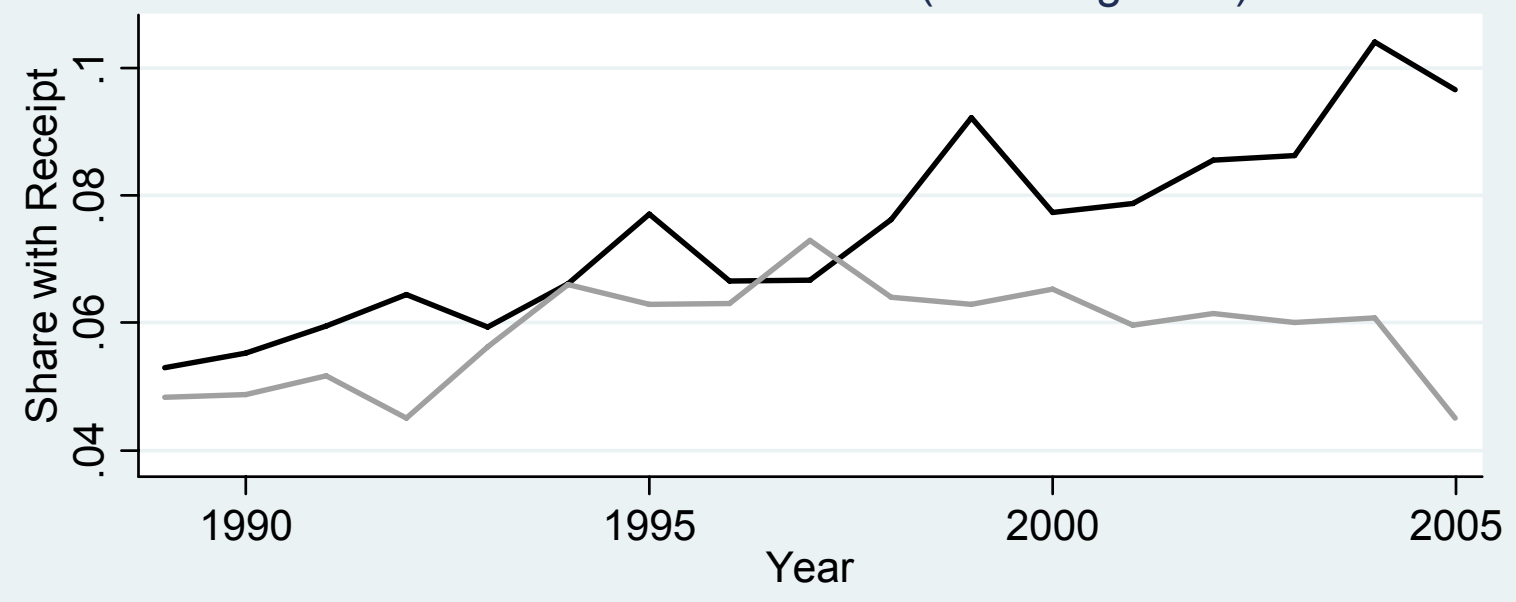

Vietnam vets, born 1944-54

Korea vets, born 1929-34

C. Share With VDC

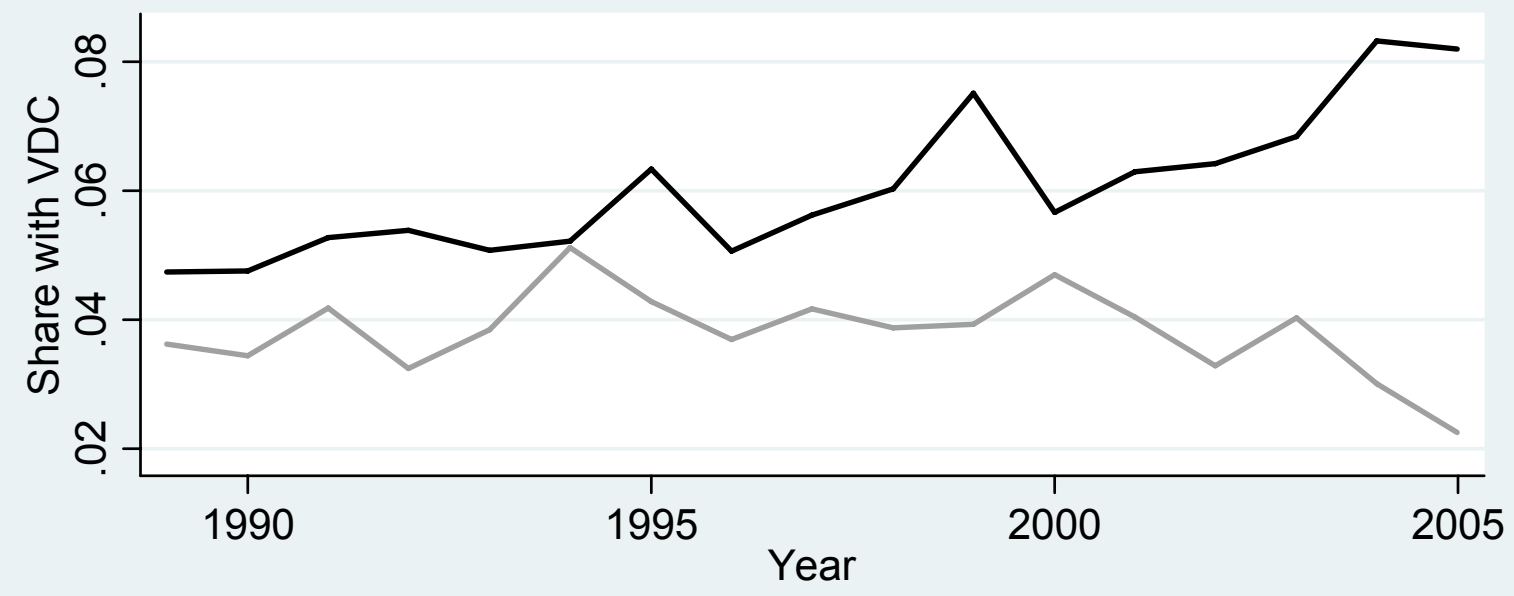

Vietnam vets, born 1944-54

Korea vets, born 1929-34

Figure 1. VA Income and Receipt by Year and Service Era Note: Amounts are in 2005 Dollars. Data are from the March CPS. 
A. Share with Work Disability

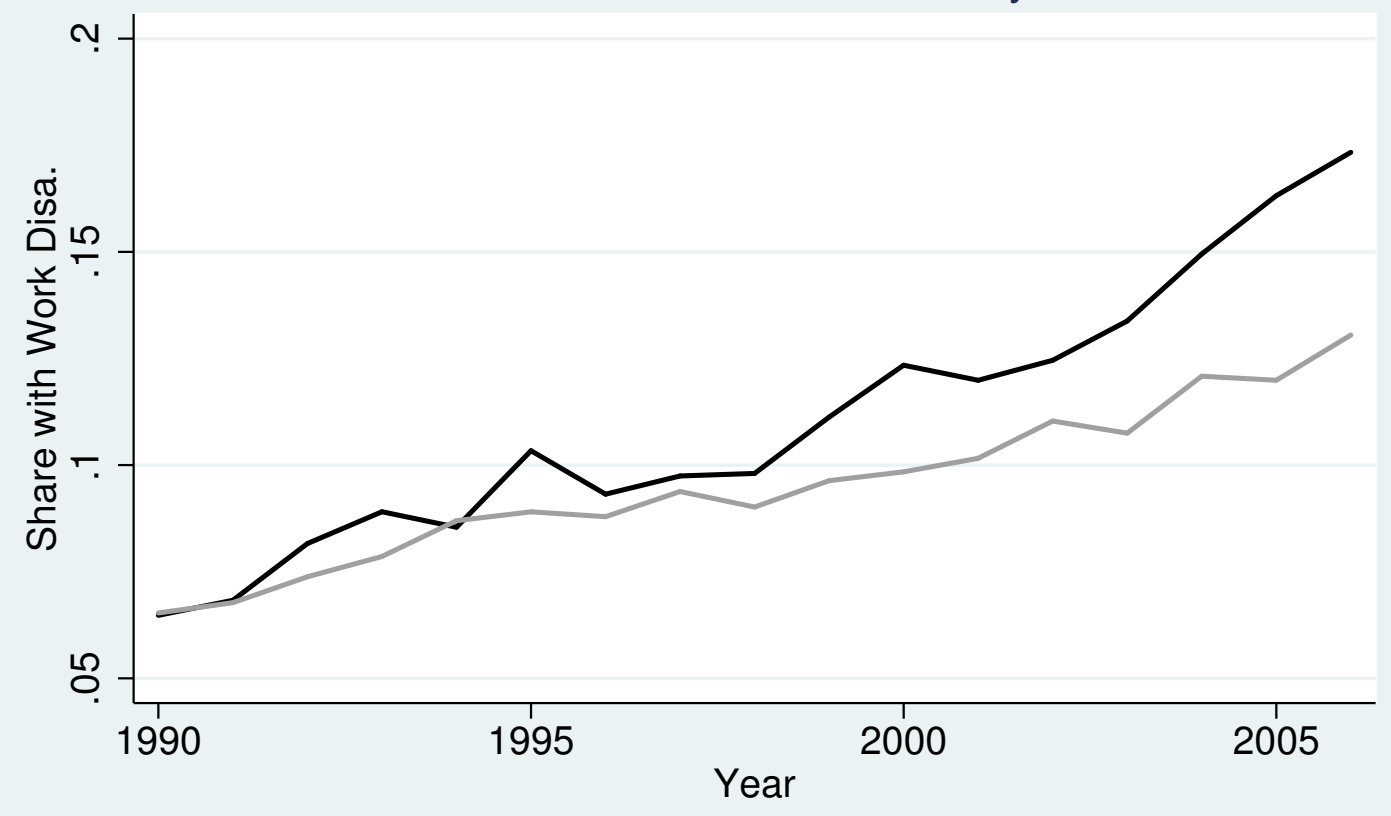

Vietnam vets, born 1944-54

B. Share with Poor Health

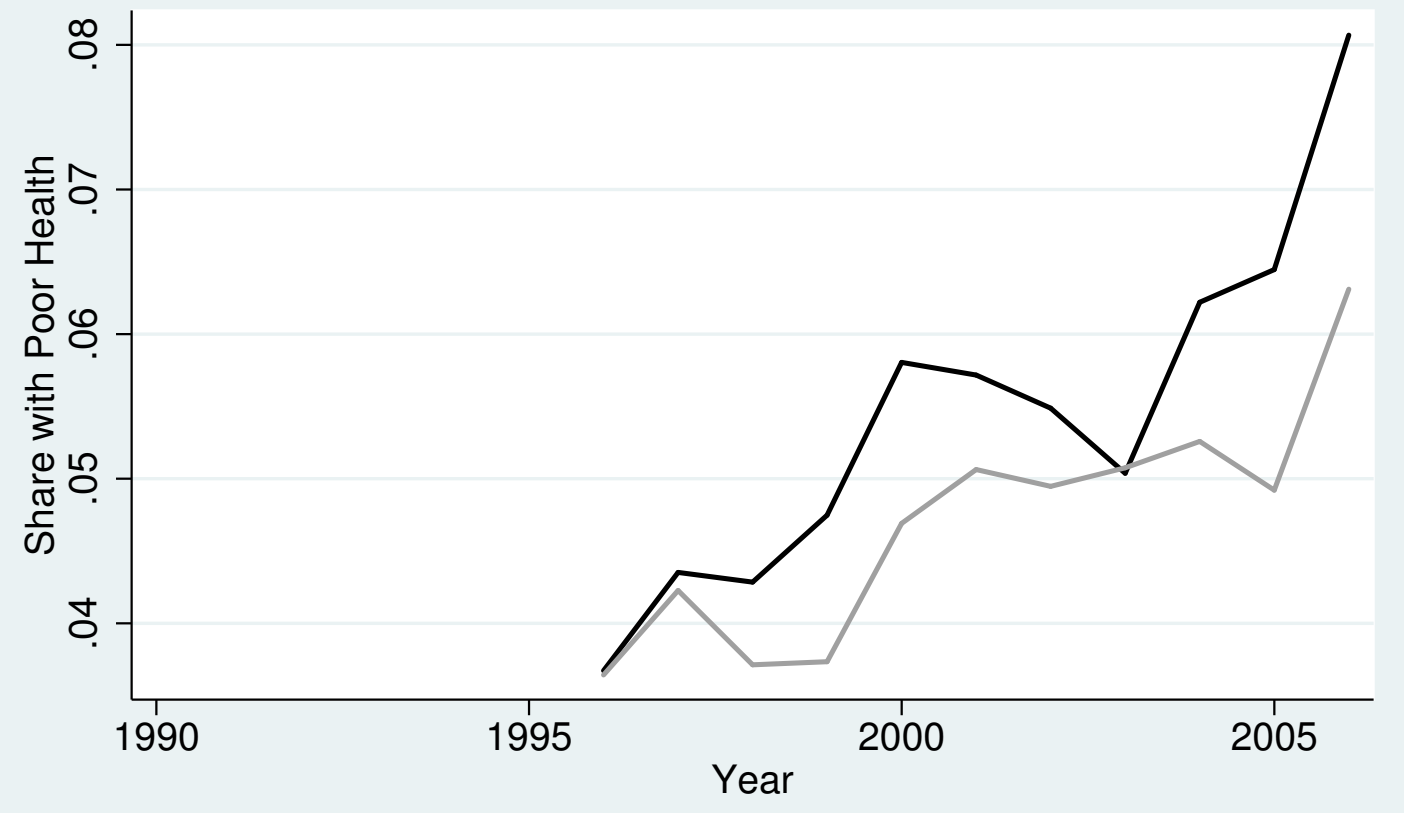

Figure 2. Work Disability and Health by Year and Veteran Status Note: Data are from the March CPS. 


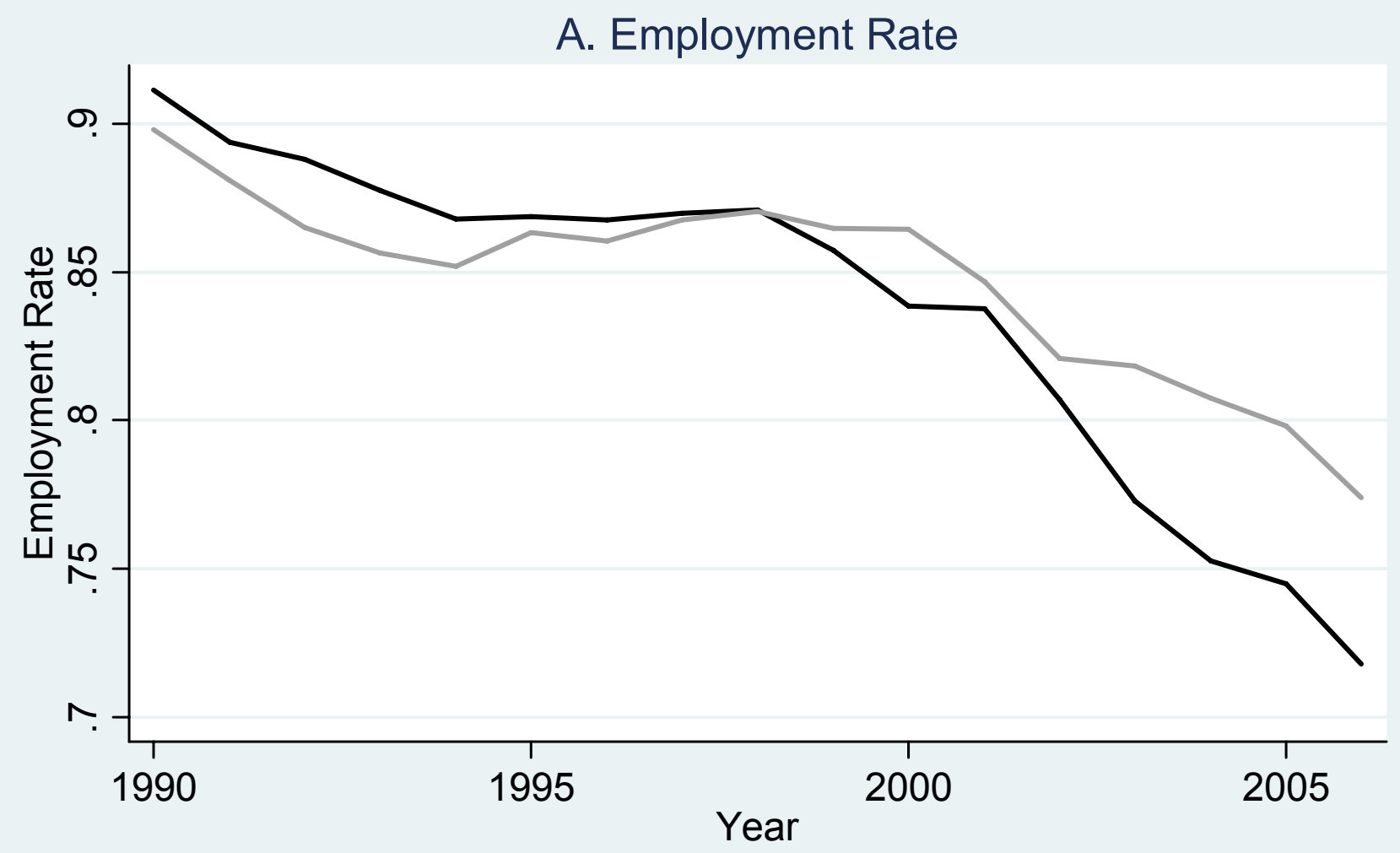

Vietnam vets, born 1944-54

Non-vets, born 1944-54

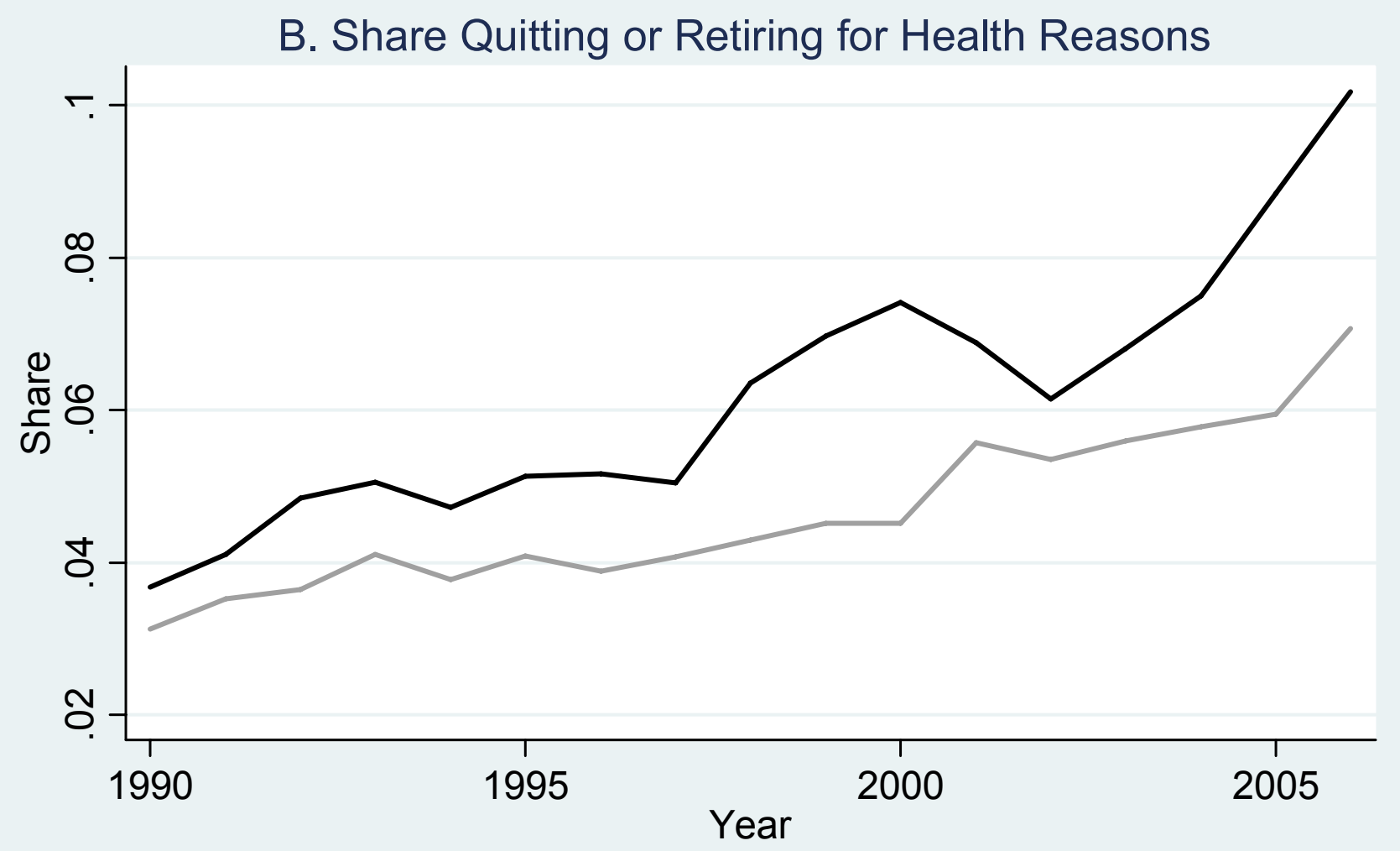

Figure 3. Employment and Health-Related Labor Force Exit by Year and Veteran Status

Note: Data are from the March CPS. 